\title{
Genetic Heterogeneity of SLC22 Family of Transporters in Drug Disposition
}

\author{
Elisa Lozano ${ }^{1,2}$, Oscar Briz ${ }^{1,2}$, Rocio I. R. Macias ${ }^{1,2}$, Maria A. Serrano ${ }^{1,2}$, Jose J. G. Marin ${ }^{1,2, *}$ (i) \\ and Elisa Herraez ${ }^{1,2}$ \\ 1 Experimental Hepatology and Drug Targeting (HEVEFARM), University of Salamanca, IBSAL, \\ 37007 Salamanca, Spain; elisa_biologia@usal.es (E.L.), obriz@usal.es (O.B.); rociorm@usal.es (R.I.R.M.), \\ maserrano@usal.es (M.A.S.), elisah@usal.es (E.H.) \\ 2 Center for the Study of Liver and Gastrointestinal Diseases (CIBERehd), \\ Carlos III National Institute of Health, 28029 Madrid, Spain \\ * Correspondence: jjgmarin@usal.es; Tel.: +34-663-182-872; Fax: +34-923-294-669
}

Received: 28 February 2018; Accepted: 10 April 2018; Published: 16 April 2018

\begin{abstract}
An important aspect of modern medicine is its orientation to achieve more personalized pharmacological treatments. In this context, transporters involved in drug disposition have gained well-justified attention. Owing to its broad spectrum of substrate specificity, including endogenous compounds and xenobiotics, and its strategical expression in organs accounting for drug disposition, such as intestine, liver and kidney, the SLC22 family of transporters plays an important role in physiology, pharmacology and toxicology. Among these carriers are plasma membrane transporters for organic cations (OCTs) and anions (OATs) with a marked overlap in substrate specificity. These two major clades of SLC22 proteins share a similar membrane topology but differ in their degree of genetic variability. Members of the OCT subfamily are highly polymorphic, whereas OATs have a lower number of genetic variants. Regarding drug disposition, changes in the activity of these variants affect intestinal absorption and target tissue uptake, but more frequently they modify plasma levels due to enhanced or reduced clearance by the liver and secretion by the kidney. The consequences of these changes in transport-associated function markedly affect the effectiveness and toxicity of the treatment in patients carrying the mutation. In solid tumors, changes in the expression of these transporters and the existence of genetic variants substantially determine the response to anticancer drugs. Moreover, chemoresistance usually evolves in response to pharmacological and radiological treatment. Future personalized medicine will require monitoring these changes in a dynamic way to adapt the treatment to the weaknesses shown by each tumor at each stage in each patient.
\end{abstract}

Keywords: cancer; carrier; chemotherapy; mutation; pharmacology; polymorphism; tumor

\section{Introduction}

Owing to its broad spectrum of substrate specificity and strategical expression in organs accounting for drug disposition, such as intestine, liver and kidney, the SLC22 family of human proteins plays an important role in physiology, pharmacology and toxicology (Figures 1 and 2). This family includes 17 well-identified transporters, some orphan transporters and unassigned gene products, still to be fully characterized. Evolutionary analysis indicates that SLC22 transporters fall into at least six subfamilies [1]. In the present review, we will use a traditional and more simplified classification based on the electric nature of the substrates, dividing SLC22 carriers into those able to transport organic cations (OCTs) or anions (OATs).

All SLC22 proteins share a similar membrane topology [2] consisting of $12 \alpha$-helical transmembrane domains (TMD), with three highly conserved areas in their structure that are important 
for their function: a large extracellular loop with many glycosylation sites between TMD1 and TMD2; a large intracellular loop in the central region between TMD6 and TMD7 with conserved residues for phosphorylation; and some motifs in TMD9 and TMD10 that contain amino acids that are crucial for the transport activity of the protein [3]. No specific residues or domains have been found to determine the specificity of the substrate, suggesting that the three domains work in cooperation with each other [4].

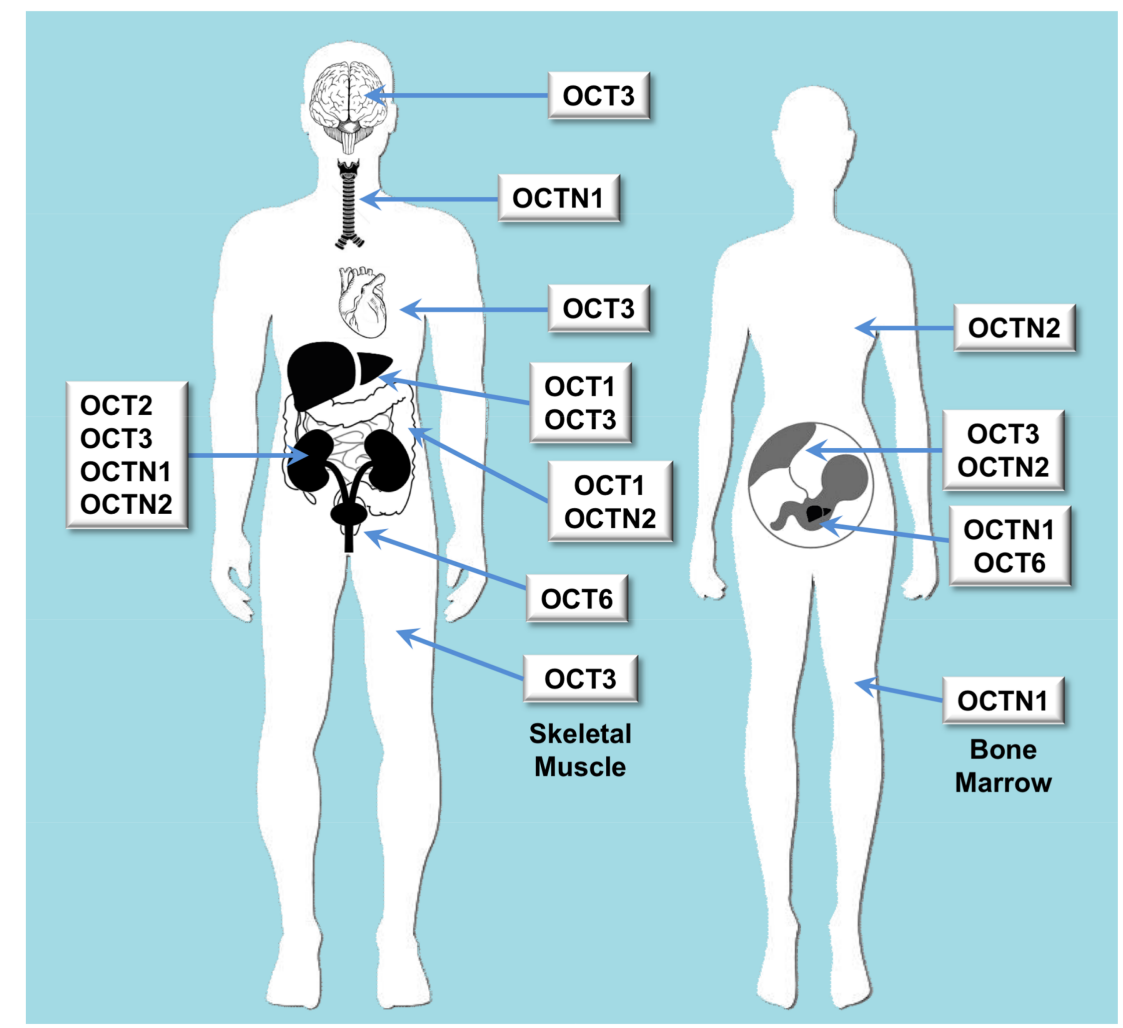

Figure 1. Scheme of the main features regarding organ distribution of proteins belonging to the SLC22 family of transporters able to transport organic cations. OCT: organic cation transporter; OCTN: organic carnitine transporter.

OCT subfamily includes three organic cation transporters (OCT1, OCT2 and OCT3). These are electrogenic facilitative transporters whose function depends on the electrochemical gradient of their substrates (Table 1). The inside-negative plasma membrane potential facilitates the uptake of their substrates, which permits to achieve intracellular concentrations up to 10-fold higher than outside the cells [5].

Phylogenetic studies of this gene subfamily suggest that it also contains a clade formed by four plasma membrane transporters of carnitine (OCTN1, OCTN2, OCTN3 and OCT6). These are electroneutral transporters that differ in their affinity for carnitine and other substrates [2] (Table 1). 
Table 1. Characteristics of the human organic cation transporters of the SLC22A family.

\begin{tabular}{|c|c|c|c|c|c|c|}
\hline Major Clade & Subclade & Gene & Protein & Tissue Distribution & Endogenous Substrates & Xenobiotic Substrates/Inhibitors \\
\hline OCT & Oct & $S L C 22 A 1$ & OCT1 & $\begin{array}{l}\text { Liver and to a less extent also } \\
\text { in brain, heart, immune cells, } \\
\text { intestine, kidney and lung }\end{array}$ & $\begin{array}{l}\text { Biogenic monoamines, biogenic } \\
\text { polyamines, catecholamines, } \\
\text { ethanolamines, neuromodulators, } \\
\text { vitamins, prostaglandins }\end{array}$ & $\begin{array}{l}\text { Cimetidine, ciprofloxacin, } \\
\text { famotidine, lamivudine, lamotrigine, } \\
\text { metformin, O-desmethyltramadol, } \\
\text { ondansetron, quinidine, ranitidine, } \\
\text { sumatriptan, tropisetron, zalcitabine }\end{array}$ \\
\hline OCT & Oct & $S L C 22 A 2$ & OCT2 & Kidney, brain, lung & $\begin{array}{l}\text { Acetylcholine, dopamine, } \\
\text { serotonin }\end{array}$ & $\begin{array}{l}\text { Amantadine, anti-malarials, atenolol, } \\
\text { cimetidine, entecavir, } \\
\text { fluoroquinolones, metformin, } \\
\text { procainamide, quinidine, sulpiride }\end{array}$ \\
\hline OCT & Oct & SLC22A3 & OCT3 & Widely expressed & Norepinephrine & Metformin, wogonin \\
\hline OCT & Octn & $S L C 22 A 4$ & OCTN1 & $\begin{array}{l}\text { Kidney, bone marrow, } \\
\text { trachea, fetal liver (at lower } \\
\text { levels in many tissues) }\end{array}$ & Acetylcholine, carnitine & $\begin{array}{l}\text { Ergothioneine, entecavir, } \\
\text { fluoroquinolones, gabapentin, } \\
\text { sulpiride }\end{array}$ \\
\hline OCT & Octn & SLC22A5 & OCTN2 & $\begin{array}{l}\text { Intestine, kidney, placenta, } \\
\text { mammary gland }\end{array}$ & Carnitine & $\begin{array}{l}\text { Entecavir, fluoroquinolones, } \\
\text { sulpiride }\end{array}$ \\
\hline
\end{tabular}




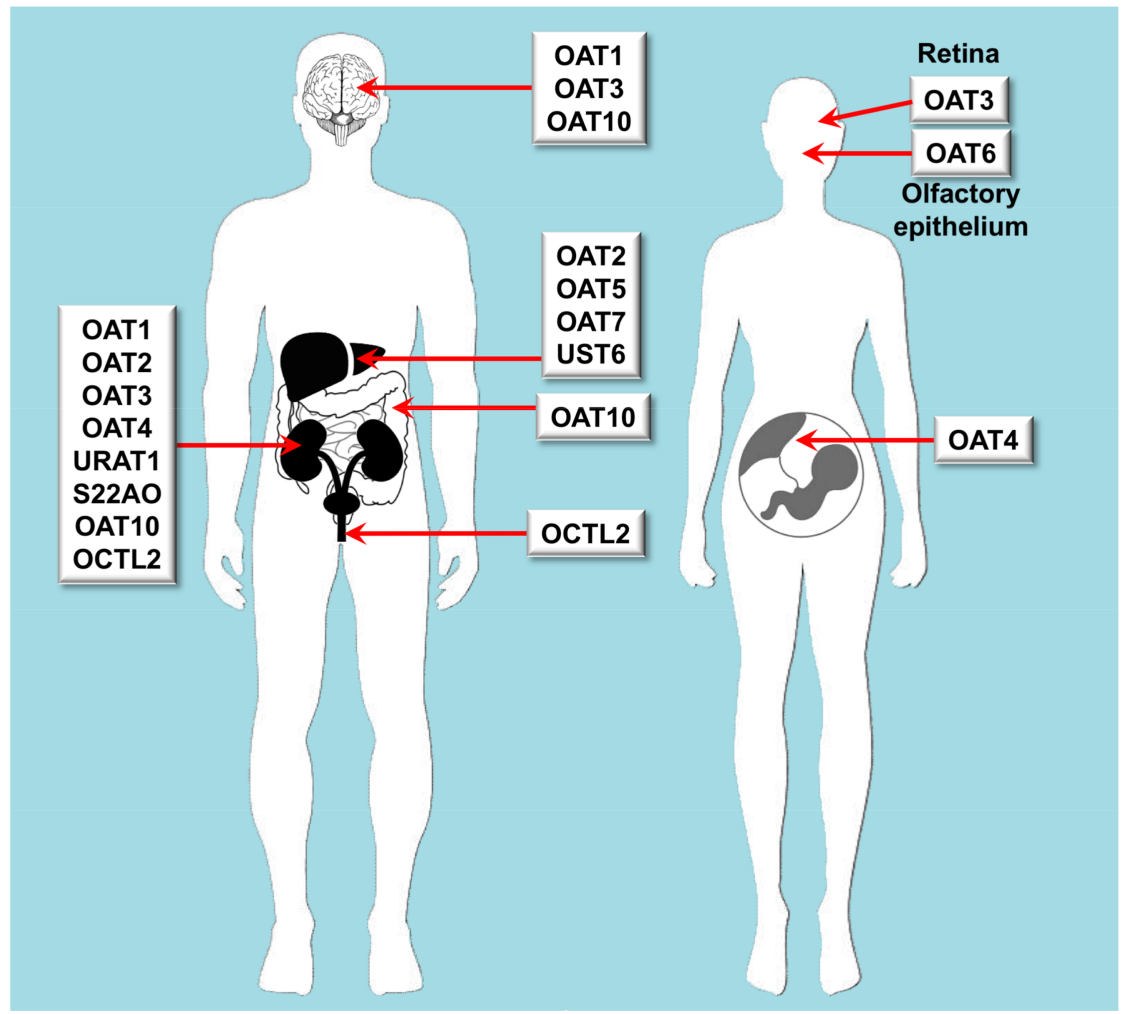

Figure 2. Scheme of the main features regarding organ distribution of proteins belonging to the SLC22 family of transporters able to transport organic anions. OAT: organic anion transporter. OCTL: organic cation transporter-like; S22AO: SLC22A orphan; URAT: urate transporter; UST: unknown substrate transporter.

The OAT subfamily is also divided into clades [3]. The major clade contains 15 genes, which can be divided into three subclades: the Oat, which is formed by the best functionally characterised organic anion transporters, the Oat-like, and the Oat-related, whose members seem to be able to transport organic cations [3]. The energy driving the function of these proteins is not yet fully understood. Some OATs work as anion exchangers, the driving force for substrate uptake being the outward gradient of intracellular dicarboxylates, generally $\alpha$-ketoglutarate, but also succinate or even monocarboxylates such as lactate [6]. OATs play their main physiological role in the kidney, although in the liver and other organs some OAT transporters can also participate in the transport of endogenous compounds and xenobiotics (Table 2), playing important roles in pharmacology and toxicology. For instance, there are OAT single nucleotide polymorphisms (SNPs) that affect the sensitivity to several nephrotoxic compounds $[7,8]$. However, it has been argued that in many cases, SNPs in multiple OATs and apical organic anion transporters may be necessary to bring out a different phenotype [9]. 
Table 2. Characteristics of the human organic anion transporters of the SLC22A family.

\begin{tabular}{|c|c|c|c|c|c|c|}
\hline $\begin{array}{l}\text { Major } \\
\text { Clade }\end{array}$ & Subclade & Gene & Protein & $\begin{array}{c}\text { Tissue } \\
\text { Distribution }\end{array}$ & Endogenous Substrates & $\begin{array}{c}\text { Xenobiotic } \\
\text { Substrates/Inhibitors }\end{array}$ \\
\hline OAT & Oat & $S L C 22 A 6$ & OAT1 & Kidney, brain & $\begin{array}{l}\text { cGMP, C5- and C6-mono and } \\
\text { dicarboxylates, } \\
\text { prostaglandins, urate }\end{array}$ & $\begin{array}{l}\text { Acyclovir, adefovir, captopril, } \\
\text { cidofovir, cimetidine, } \\
\text { furosemide, ganciclovir, } \\
\text { methotrexate, olmesartan, } \\
\text { tenofovir, ranitidine }\end{array}$ \\
\hline OAT & Oat & SLC22A7 & OAT2 & Liver, kidney & $\begin{array}{l}\text { Conjugated steroid } \\
\text { hormones, cGMP, } \\
\text { nucleobases, nucleosides, } \\
\text { nucleotides, prostaglandins }\end{array}$ & $\begin{array}{l}\text { Acyclovir, cimetidine, } \\
\text { diclofenac, entecavir, } \\
\text { erythromycin, ganciclovir, } \\
\text { irinotecan, methotrexate, } \\
\text { penciclovir, ranitidine, } \\
\text { tetracycline, 5-FU }\end{array}$ \\
\hline OAT & Oat & $S L C 22 A 8$ & OAT3 & $\begin{array}{l}\text { Kidney, retina, } \\
\text { brain }\end{array}$ & $\begin{array}{l}\text { Acidic neurotransmitter } \\
\text { metabolites, bile acids, } \\
\text { C5-dicarboxylates, cAMP, } \\
\text { cGMP, conjugated steroid } \\
\text { hormones, prostaglandins, } \\
\text { urate }\end{array}$ & $\begin{array}{l}\text { Cimetidine, benzylpenicillin, } \\
\text { bumetanide, cephalosporins, } \\
\text { ciprofloxacin, furosemide, } \\
\text { methotrexate, NSAIDs, } \\
\text { pravastatin, probenecid, } \\
\text { rosuvastatin, zidovudine }\end{array}$ \\
\hline OAT & Oat & SLC22A9 & OAT7 & Liver & $\begin{array}{l}\text { Conjugated steroid } \\
\text { hormones, monocarboxylates, } \\
\text { short chain fatty acids }\end{array}$ & Pravastatin \\
\hline OAT & Oat & SLC22A10 & OAT5 & Liver & Unknown & \\
\hline OAT & Oat & SLC22A11 & OAT4 & $\begin{array}{l}\text { Kidney, placenta, } \\
\text { adrenal gland }\end{array}$ & $\begin{array}{l}\text { Bile acids, C5-dicarboxylates, } \\
\text { conjugated steroid hormones } \\
\text { prostaglandins, urate }\end{array}$ & $\begin{array}{l}\text { Bumetanide, } \\
\text { hydrochlorothiazide, } \\
\text { ketoprofen, methotrexate, } \\
\text { salicylate, tetracycline, } \\
\text { torsemide, zidovudine }\end{array}$ \\
\hline OAT & Oat & SLC22A12 & URAT1 & Kidney & Urate & \\
\hline OAT & Oat & SLC22A20 & OAT6 & $\begin{array}{l}\text { Nasal epithelial } \\
\text { cells }\end{array}$ & $\begin{array}{l}\text { Conjugated steroid } \\
\text { hormones, C5-dicarboxylates, } \\
\text { short chain fatty acids }\end{array}$ & Sorafenib \\
\hline OAT & Oat & SLC22A24 & $\mathrm{S} 22 \mathrm{AO}$ & Kidney & Unknown & \\
\hline OAT & Oat & SLC22A25 & UST6 & Liver & Unknown & \\
\hline OAT & Oat-like & $S L C 22 A 13$ & OAT10 & $\begin{array}{l}\text { Kidney, brain, } \\
\text { colon }\end{array}$ & $\begin{array}{l}\text { C4-dicarboxylates, } \\
\text { glutathione, nicotinate, urate }\end{array}$ & \\
\hline OAT & Oat-like & SLC22A14 & OCTL2 & Testis, kidney & Unknown & \\
\hline
\end{tabular}

\section{Carriers for Organic Cations}

OCT1 (SLC22A1) is mainly expressed at the sinusoidal membrane of hepatocytes, but also in small intestine, lung, placenta, heart, skeletal muscle, brain, eye and immune system cells [10]. Although some weak bases and non-charged compounds can be transported, most OCT1 substrates are organic cations, such as the model substrates tetraethylammonium (TEA), $\mathrm{N}$-methylquinine, and 1-methyl-4-phenylpyridinium (MPP), and endogenous compounds, such as catecholamines (dopamine, epinephrine or norepinephrine) [11], choline [2], histamine, serotonin, spermidine [11], putrescine [12], some vitamins, such as thiamine [13] or $N^{1}$-methylnicotinamide [14] and the neuromodulator histidyl-proline diketopiperazine [15]; they are rarely organic anions such as prostaglandins $\mathrm{E}_{2}$ and $\mathrm{F}_{2 \alpha}[16]$.

OCT2 (SLC22A2) is expressed at the basolateral membrane of tubular epithelial cells of the kidney [17], in several areas of the brain [18]; where it transports biogenic amine neurotransmitters, such as dopamine, and serotonin, and in lung [19]; where it mediates the luminal release of acetylcholine. OCT2 can transport substrates in a bi-directional manner [18,19] and prefers smaller substrates than OCT1.

OCT3 (SLC22A3) has a broad tissue distribution, with high expression in liver, skeletal muscle, heart, kidney and placenta [20,21]; but also in small intestine, brain, uterus, or salivary glands [22]. There is high expression of OCT3 in brown adipose tissue, where it could play a role as regulator of norepinephrine in the extracellular space [23]. Like OCT1 and OCT2, OCT3 transports predominantly organic cations, but also some uncharged molecules. 
OCTN1 (SLC22A4) is expressed in renal epithelium, bone marrow, trachea and fetal liver and, at a lower level, in other tissues, such as prostate, spleen, spinal cord and eye [24,25]. OCTN1 mediates organic cation transport in a bidirectional and $\mathrm{pH}$-dependent manner. Although it was initially described as a carnitine transporter, the xenobiotic amino acid ergothioneine is now considered its main physiological substrate [26]. OCTN1 has also been involved in acetylcholine transport [27]. Together with the localization at the plasma membrane, OCTN1 has been also detected at the mitochondria [28].

OCTN2 (SLC22A5) is predominantly expressed in polarized epithelial cells of intestine, kidney, placenta, and mammary gland, and at lower levels in many other tissues [29]. In the same way as OCTN1, OCTN2 can take up carnitine and other organic cations in a sodium-independent and dependent manner [30]. OCTN2 is considered the main transporter responsible for carnitine homeostasis, participating in its intestinal absorption and tissue distribution.

OCTN3 was first identified in mice. A human orthologue has been identified [31] and localized at the peroxisomes. Accordingly, has been postulated to be a peroxisomal membrane transporter with a unique role in the maintenance of intracellular carnitine homeostasis [32]. OCT6 (SLC22A16), also known as CT2, has a unique pattern of tissue distribution, being mainly expressed in testis, hematopoietic cells and fetal liver. OCT6 is able to transport carnitine, but no other typical substrates of OCTs/OCTNs [33].

\subsection{Role of Organic Cation Transporters in Drug Disposition}

Owing to the pivotal role of the liver in the metabolism of endogenous compounds and xenobiotics, impaired function of liver transporters can have an important impact on drug disposition and distribution. The kidney also plays a key role in excreting water-soluble drugs or their derivatives. Inhibition of renal drug transport can affect drug plasma concentrations, leading to altered pharmacological effects and/or adverse drug reactions. Drug-drug interactions due to cross-inhibition of plasma membrane transporters, leading to impaired elimination/uptake of one drug in the presence of another, are frequently responsible for altered pharmacokinetic and problems of safety and efficacy. The International Transporter Consortium included OCTs/OCTNs among the transporters clinically important in drug absorption and disposition, and recommended in vitro methods to study transporter-drug interactions [34].

Among many drugs that can be transported by OCT1 the most relevant ones are shown in Table 1 and commented below. Metformin used for the treatment of type II diabetes, is taken up by the liver and intestine via OCT1. Metformin was the first described OCT1 substrate. [35]. The anti-retroviral lamivudine, used to prevent human immunodeficiency virus (HIV) replication, is efficiently taken up by OCT1 [36]. Because this transporter is also expressed in mononuclear cells of the lymph nodes, it has been proposed that it could participate in the accumulation of lamivudine in lymph nodes of HIV-infected patients. Zalcitabine, another anti-retroviral drug, is also taken up by OCT1 [36]. $\mathrm{O}$-desmethyltramadol is an opioid analgesic and the main active metabolite of tramadol. OCT1 is involved in the uptake of this drug by the liver, which is a key factor affecting the efficacy of tramadol treatment [37]. OCT1 is a high-capacity transporter of the anti-migraine drug sumatriptan [38] and the anti-emetics tropisetron and ondansetron. Impaired OCT1 function may increase the efficacy of these drugs by limiting their hepatic clearance [39]. Assays carried out both in vitro and in vivo suggest that OCT1 mediates morphine uptake by hepatocytes and that the lack of OCT1 activity results in significantly higher concentrations of morphine in plasma. In contrast to morphine, codeine is an inhibitor, but not a substrate of OCT1 [40]. Experiments using Xenopus laevis oocytes demonstrated that OCT1 transports histamine-2 (H2) receptor antagonists. Thus, OCT1 is likely to play a major role in the intestinal absorption and hepatic disposition of the $\mathrm{H} 2$ receptor antagonists ranitidine and famotidine [41]. Moreover, in vitro studies have demonstrated that the $\mathrm{H} 2$ receptor antagonist cimetidine [42], the anti-arrhythmic quinidine [43], antibiotics of the fluoroquinolone family, such as ciprofloxacin [44] and the anti-convulsant drug lamotrigine [45] are also substrates of OCT1. 
OCT2 is also involved in metformin disposition. This drug is mainly eliminated unchanged in urine after tubular secretion, which is mediated by OCT2 [46]. Sulpiride is a selective dopamine D2 receptor blocker used in the treatment of patients with schizophrenia and depression. OCT2 also accounts for the uptake of this drug by proximal tubular cells from the bloodstream [47]. The anti-malarial drugs proguanil and cycloguanil, the anti-retroviral entecavir, and anti-hypertensive atenolol are also substrates of OCT2, while amodiaquine, pyrimethamine and quinine are inhibitors of this transporter [48-50]. Cimetidine, anti-arrhythmic drugs quinidine and procainamide, and the anti-retroviral amantadine, are also inhibitors of both OCT2 and OCT1 [51]. Moreover, OCT2 and/or OCT3 mediate the accumulation of fluoroquinolones in renal proximal tubule cells [52].

Due to the ubiquitous expression of OCT3, it has been suggested that this transporter can play a role in drug distribution and elimination. In fact, data obtained in Oct3 knockout mice demonstrated that this transporter also participates in the absorption and elimination of metformin, and determines its bioavailability, clearance, and pharmacologic action [53]. The high expression of OCT3 in salivary glands is responsible for metformin accumulation and secretion into saliva, which could explain its known effect in taste disturbance [22]. Scutellaria baicalensis is a popular plant, used in Chinese traditional medicine for the treatment of inflammation, hypertension, and infections. One of its components, wogonin, impairs cellular influx of drugs into renal tubular cells via OCT3 inhibition [54]. Because OCT3 is expressed at the apical membrane of enterocytes, this carrier can also affect the bioavailability of drugs by modifying their intestinal absorption. Although the cationic drug salbutamol, a beta-2 agonist used as anti-asthmatic, has been reported to be a substrate of OCTs, and OCT3 is highly expressed at the airway epithelium, there is evidence suggesting that salbutamol enters bronchial smooth muscle cells via a transporter-independent way. Surprisingly, salbutamol uptake is affected, through an unknown mechanism, by corticosterone and beclomethasone [55].

OCTN1 and OCTN2 participate in both renal secretion and reabsorption of sulpiride [47] and entecavir [49], and could mediate the efflux of fluoroquinolones into urine after being accumulated in renal proximal tubule cells [52]. OCTN1 also mediates the renal secretion of gabapentin, a drug used to treat seizures, and post-herpetic neuralgia [56].

Regarding OCT6, little is known about its role in drug disposition. Only interaction with anti-tumor drugs has been described. Thus, decreased OCT6 expression in lung cancer cells has been associated with a reduced intracellular uptake of cisplatin and oxaliplatin, and concomitant enhanced resistance to these platinum-containing drugs [57].

\subsection{Impact of Genetic Variability in Pharmacokinetics}

The gene encoding OCT1, i.e., SLC22A1, is highly polymorphic. Approximately $10 \%$ of Caucasians are homozygous carriers and $40 \%$ are heterozygous carriers of a loss-of-function OCT1 allele [39]. Two of the OCT1 polymorphic variants (OCT1-C88R and OCT1-G465R) have been observed only in combination with the variant OCT1-M420del. The haplotype combining OCT1-C88R and OCT1-M420del is designed allele OCT1*6, whereas the haplotype with OCT1-G465R and OCT1-M420del is designed allele OCT1*5. Moreover, shorter OCT1 isoforms originated by aberrant splicing due to exon skipping and intron retention sequences are also expressed. These OCT1 variants result in truncated nonfunctional proteins [58].

Several OCT1 variants have been associated with impaired/reduced drug uptake (Table 3). Thus, genetic variation in OCT1 has been associated with the pharmacokinetic performance of metformin. On one hand, a clinical study in healthy volunteers indicated that plasma glucose levels after metformin treatment were higher in people carrying OCT1 polymorphisms (OCT1-R61C, G401S, M420del, and G465R which exhibited reduced uptake of metformin in the cellular assays) than in those carrying the wild-type OCT1 sequence. This may be related to dynamic differences in metformin levels in the intestine between individuals with and without these variants, which may affect metformin absorption [59]. In a clinical study with type-II diabetes mellitus patients only the intronic variant rs622342 of all studied variants was associated with the glucose-lowering effect of metformin [60]. 
In addition to direct efficacy of metformin, OCT1 variants have been associated with the secondary effects of this drug. Thus, the variant c.1276 + 1insGTAAGTTG ( $r s 36056065)$, which consists of an 8-bp insertion of intron 7 between exons 7 and 8, results in a truncated protein that has been associated with adverse gastrointestinal side effects in patients treated with metformin [61]. It has been hypothesized that metformin intolerance in these patients is induced by a local increase of drug concentrations in the intestine. The association of OCT1 variants and gastrointestinal side effects of metformin therapy was also identified in patients with OCT1-M408V variant [61], although it had been described that this SNP mediates normal metformin uptake in vitro [59]. Disposition of morphine could be also modulated by OCT1 genotypes. Thus, in vitro studies indicated that OCT1 variants OCT1-G401S, OCT1*5 and OCT1*6 were not able to transport morphine, and M420del and R61C variants showed very limited transport capacity compared to wild-type OCT1. When the effect of these SNPs was studied in clinical assays, it was found that the presence of these polymorphisms resulted in higher morphine plasma concentrations due to lower hepatic clearance [40]. Another study indicated that OCT1 genotypes largely determine the pharmacokinetics of intravenously injected morphine. Defective OCT1 variants potentially lead to a reduced clearance of morphine and consequently to a higher frequency of drug-induced toxicity episodes [62,63].

The anti-emetic drug tropisetron is primarily metabolized in hepatocytes after been taken up through OCT1. Variants of this transporter have been postulated to alter tropisetron response. SNPs that reduce OCT1 function, such as R61C, G401S, M420del, OCT1*5 and OCT1*6, have been associated with increased tropisetron plasma concentrations due to poorer hepatic clearance and consequently with a better response to this treatment in patients bearing these variants [39]. Reduced OCT1 function may be expected to increase the efficacy of ondansetron, another antiemetic drug, by limiting their hepatic clearance; however, clinical assays did not show a significant association between impaired OCT1 function and a better response to this drug [39].

In a population-based cohort study, the polymorphism c.1386A $>C$ ( $r s 622342)$, localized in a non-coding region of the SLC22A1 gene, was associated with higher prescribed doses of anti-Parkinson drugs and a shorter survival after start of levodopa therapy [64]. There are two possible explanations for this association: (i) it is possible that the $r s 622342 \mathrm{C}$ allele accounts for a reduced anti-Parkinson drug uptake by the small intestine and hence is responsible for a lower bioavailability [65]; (ii) OCT1, which is expresses at low levels in the brain, can act as rate-limiting step for drug uptake by this target tissue.

In a cohort of Chinese patients with epilepsy, the OCT1-M408V (c.1222A>G) polymorphism was significantly associated with serum concentrations of lamotrigine. Results indicated that these were $26 \%$ lower in patients with GG genotype compared with AA and AG genotypes. These findings suggested that patients with GG genotype required higher maintenance dose of lamotrigine to achieve similar plasma levels [66]. These effects could be due to OCT1-mediated hepatic uptake of this drug and/or to the fact that, as has been demonstrated in in vitro assays, lamotrigine is taken up by brain endothelial cells through OCT1 [66].

Results from in vitro experiments have revealed that some OCT1 polymorphisms (R61C, G401S, M420del, OCT1*5 and OCT1*6) result in impaired O-desmethyltramadol transport by this carrier. Clinical data indicate that healthy volunteers carrying these variants with loss of function, also present higher plasma concentrations of the $O$-desmethyltramadol together with high concentrations in the central nervous system, which is probably due to reduced hepatic clearance of this drug [37].

OCT1 may be involved in the transport of the antidepressants amisulpride and sulpiride in the brain. In vitro studies demonstrate a strong reduction of the OCT1-mediated uptake of both drugs by the five most common OCT1 loss-of-function alleles (R61C, G401S, M420del, OCT1*5 and OCT1*6 [67].

OCT1-mediated uptake is a limiting step in the hepatic metabolism of sumatriptan. Clinical data indicated that genetically determined loss of OCT1 activity (OCT1-R61C, C88R, G401S, G465R) results in two-fold increased systemic exposure to sumatriptan [38]. 
OCT1-C88R and G465R expressing cells present complete loss of lamivudine uptake in vitro [68]. Also in vitro assays have revealed that polymorphic OCT1 variants alter the uptake of the antihypertensive drug debrisoquine. Thus, the SNPs OCT1-C88R and G465R result in complete lack of debrisoquine OCT1-mediated uptake [69].

Described OCT2 SNPs (Table 3) have not been associated to changes in expression, but some induce reduced activity. Lower renal clearance of metformin has been found in patients with OCT2 variants T199I, T201M, and A270S, which lead to higher peak in plasma concentration after metformin administration [70].

The splice variant OCT2-A, although maintains $81 \%$ amino acid identity with the wild-type protein, displays different affinity for several organic cations. Because OCT2-A is mainly expressed in kidney, it is believed that the expression of OCT2-A affects the renal clearance of its substrates [71].

Among five genetic variants of OCT3 functionally characterized [72], A116S, T400I, and A439V (Table 3) have a reduced transport activity. A higher susceptibility of hypertension, allergic diseases and psychiatric disorders in subjects bearing these genetic variants has been reported and suggested to be associated with a reduced local clearance of histamines and neurotransmitters in the nervous system.

At least 15 SNPs of OCNT1 have been characterized (Table 3). A reduced transport activity was reported for G462E [73] and M205I [74], while variants D165G and R282X resulted in complete loss of transport function [74]. In Chinese and Indian populations, eight SNPs have been described [75]. Four of these variants: R63H, R83P, G482D, and I500N presented a reduced uptake capacity. Moreover, a reduced tubular secretion of gabapentin in patients with the L503F variant was found [56]. 
Table 3. Genetic variants in human organic cation transporters of the SLC22A family.

\begin{tabular}{|c|c|c|c|c|c|}
\hline $\begin{array}{l}\text { Transporter } \\
\text { (Gene) }\end{array}$ & Genetic Polymorphism & $\begin{array}{l}\text { Amino Acid } \\
\text { Change }\end{array}$ & $\begin{array}{l}\text { Effect on } \\
\text { Expression }\end{array}$ & Activity & Effect on Drug Disposition \\
\hline \multirow{10}{*}{$\begin{array}{c}\text { OCT1 } \\
(\mathrm{SLC} 22 \mathrm{~A} 1)\end{array}$} & c. $181 \mathrm{C}>\mathrm{T}$ & $\mathrm{R} 61 \mathrm{C}$ & $=$ & Reduced & $\begin{array}{l}\text { Reduced intestinal uptake of metformin } \\
\text { Higher plasma concentrations of O-desmethyltramadol, } \\
\text { sumatriptan, morphine, tropisetron, ondansetron }\end{array}$ \\
\hline & c. $252 \mathrm{~T}>\mathrm{C}$ & C88R & $=$ & Reduced & Increased systemic exposure to sumatriptan \\
\hline & c. $1201 G>A$ & G401S & $=$ & Reduced & $\begin{array}{l}\text { Reduced intestinal uptake of metformin } \\
\text { Higher plasma concentrations of O-desmethyltramadol, } \\
\text { sumatriptan, morphine, tropisetron, ondansetron }\end{array}$ \\
\hline & c. $1222 \mathrm{~A}>\mathrm{G}$ & M408V & $=$ & Similar & Gastrointestinal side-effects of metformin \\
\hline & c.1258_1260delATG & M420del & $=$ & Reduced & $\begin{array}{l}\text { Alteration of lamotrigine serum concentration } \\
\text { Reduced intestinal uptake of metformin } \\
\text { Higher plasma concentrations of O-desmethyltramadol, } \\
\text { morphine, tropisetron, ondansetron }\end{array}$ \\
\hline & c. $1386 \mathrm{~A}>\mathrm{C}(\mathrm{rs} 622342)$ & - & $\downarrow$ Expected & Reduced & Low effect of metformin, levodopa \\
\hline & c. $1393 \mathrm{G}>\mathrm{C}$ & G465R & $=$ & Reduced & $\begin{array}{l}\text { Reduced intestinal uptake of metformin } \\
\text { Increased systemic exposure to sumatriptan }\end{array}$ \\
\hline & $\mathrm{OCT}^{*} 5$ & G465R + M420del & $=$ & Reduced & $\begin{array}{l}\text { Higher plasma concentrations of O-desmethyltramadol, } \\
\text { morphine, tropisetron and ondansetron }\end{array}$ \\
\hline & OCT1*6 & C88R + M420del & $=$ & Reduced & $\begin{array}{l}\text { Higher plasma concentrations of O-desmethyltramadol, } \\
\text { morphine, tropisetron and ondansetron }\end{array}$ \\
\hline & $\begin{array}{l}\text { rs36056065 (c.1276 + 1ins } \\
\text { GTAAGTTG) }\end{array}$ & - & Aberrant splicing & & Gastrointestinal side-effects of metformin \\
\hline \multirow{6}{*}{$\begin{array}{c}\mathrm{OCT} 2 \\
(\mathrm{SLC} 22 \mathrm{~A} 2)\end{array}$} & c. $495 \mathrm{G}>\mathrm{A}$ & M165I & & Reduced & \\
\hline & c.596C >G & T199I & & Reduced & Reduced renal clearance of metformin \\
\hline & c. $602 \mathrm{C}>\mathrm{T}$ & $\mathrm{T} 201 \mathrm{M}$ & & Reduced & Reduced renal clearance of metformin \\
\hline & c. $808 \mathrm{G}>\mathrm{T}$ & A270S & & Reduced & Reduced renal clearance of metformin \\
\hline & c. $1198 \mathrm{C}>\mathrm{T}$ & $\mathrm{R} 400 \mathrm{C}$ & & Reduced & \\
\hline & c. $1294 \mathrm{~A}>\mathrm{C}$ & K432Q & & Similar & \\
\hline $\begin{array}{c}\text { OCT3 } \\
\text { (SLC22A3) }\end{array}$ & & $\begin{array}{l}\text { A116S } \\
\text { T400I }\end{array}$ & $\begin{array}{l}= \\
=\end{array}$ & $\begin{array}{l}\text { Reduced } \\
\text { Reduced }\end{array}$ & \\
\hline
\end{tabular}


Table 3. Cont

\begin{tabular}{|c|c|c|c|c|c|}
\hline $\begin{array}{c}\text { Transporter } \\
\text { (Gene) }\end{array}$ & Genetic Polymorphism & $\begin{array}{c}\text { Amino Acid } \\
\text { Change }\end{array}$ & $\begin{array}{c}\text { Effect on } \\
\text { Expression }\end{array}$ & Activity & Effect on Drug Disposition \\
\hline & & $\mathrm{A} 439 \mathrm{~V}$ & $=$ & Reduced & \\
\hline \multirow{15}{*}{$\begin{array}{c}\text { OCTN1 } \\
\text { (SLC22A4) }\end{array}$} & c. $188 \mathrm{G}>\mathrm{A}$ & $\mathrm{R} 63 \mathrm{H}$ & $\downarrow$ Membrane & Reduced & \multirow{15}{*}{ Reduced tubular secretion of gabapentin } \\
\hline & c. $248 \mathrm{G}>\mathrm{C}$ & $\mathrm{R} 83 \mathrm{P}$ & $\downarrow$ Membrane & Reduced & \\
\hline & c. $400 \mathrm{C}>\mathrm{A}$ & L134M & & Similar & \\
\hline & c. $475 \mathrm{G}>\mathrm{A}$ & V159M & & Similar & \\
\hline & c. $494 \mathrm{~A}>\mathrm{G}$ & D165G & $\downarrow$ Membrane & Lost & \\
\hline & c. $615 \mathrm{G}>\mathrm{A}$ & M205I & $\downarrow$ Membrane & Reduced & \\
\hline & c. $774 \mathrm{G}>\mathrm{C}$ & M258I & & Similar & \\
\hline & c. $844 \mathrm{C}>\mathrm{T}$ & K282X & & Lost & \\
\hline & c.917C > T & T306I & $=$ & Similar & \\
\hline & c. $1031 \mathrm{~T}>\mathrm{A}$ & M344K & & Similar & \\
\hline & c. $1445 \mathrm{G}>\mathrm{A}$ & G482D & $=$ & Reduced & \\
\hline & c. $1460 \mathrm{~T}>\mathrm{C}$ & M487T & & Similar & \\
\hline & c. $1499 \mathrm{~T}>\mathrm{A}$ & $\mathrm{I} 500 \mathrm{~N}$ & $=$ & Reduced & \\
\hline & c. $1507 \mathrm{G}>\mathrm{A}$ & L503F & $=$ & Reduced & \\
\hline & c. $1531 G>A$ & & $=$ & Reduced & \\
\hline \multirow{20}{*}{$\begin{array}{c}\text { OCTN2 } \\
\text { (SLC22A5) }\end{array}$} & c. $51 C>G$ & F17L & \multirow{7}{*}{$\downarrow$ Membrane } & Reduced & \\
\hline & c. $325 \mathrm{G}>\mathrm{C}$ & E109Q & & Similar & \\
\hline & c. $364 \mathrm{G}>\mathrm{T}$ & $\mathrm{D} 122 \mathrm{Y}$ & & Reduced & \\
\hline & c. $430 \mathrm{C}>\mathrm{T}$ & L144F & & Similar & \\
\hline & c. $523 \mathrm{G}>\mathrm{A}$ & V175M & & Similar & \\
\hline & c. $573 \mathrm{G}>\mathrm{T}$ & K191N & & Similar & \\
\hline & c. $614 \mathrm{C}>\mathrm{T}$ & $\mathrm{A} 214 \mathrm{~V}$ & & Similar & \\
\hline & c. $791 \mathrm{C}>\mathrm{T}$ & $\mathrm{T} 264 \mathrm{M}$ & \multirow{4}{*}{$\downarrow$ Membrane } & Reduced & \\
\hline & c. $904 \mathrm{~A}>\mathrm{G}$ & K302E & & Reduced & \\
\hline & c. $934 \mathrm{~A}>\mathrm{G}$ & $\mathrm{I} 312 \mathrm{~V}$ & & Similar & \\
\hline & \multirow[t]{2}{*}{ c. $949 \mathrm{G}>\mathrm{A}$} & E317K & & Higher & \\
\hline & & M352R & $=$ & Lost & \\
\hline & \multirow[t]{2}{*}{ c. $1345 \mathrm{~T}>\mathrm{G}$} & Y449D & & Reduced & \\
\hline & & P478L & $=$ & Lost & \\
\hline & \multirow[t]{2}{*}{ c. $1341 \mathrm{TG}>\mathrm{T}$} & V481F & & Reduced & \\
\hline & & V481I & & Similar & \\
\hline & c. $1463 \mathrm{G}>\mathrm{A}$ & $\mathrm{R} 488 \mathrm{H}$ & & Similar & \\
\hline & c. $1522 \mathrm{~T}>\mathrm{C}$ & F508L & & Similar & \\
\hline & c. $1588 \mathrm{~A}>\mathrm{G}$ & M530V & & Similar & \\
\hline & c. $1645 \mathrm{C}>\mathrm{T}$ & P549S & & Similar & \\
\hline
\end{tabular}


OCNT2 is highly polymorphic (Table 3). Altered transport activity of this carrier has been found in 8 out of 20 genetic OCNT2 variants characterized. Mutations M352R and P478L were associated with loss of transport function despite the protein expression is not impaired in individuals bearing these mutations [76].

\section{Carriers for Organic Anions}

Some members of the SLC22 family, globally designed here with the classical denomination of OATs, can transport a broad variety of anionic endogenous metabolites and xenobiotic molecules, including many drugs and consequently, they have an important impact on pharmacokinetics $[77,78]$ (Table 2). Most OATs are highly expressed in human kidney and/or liver, and at lower levels in brain, placenta, prostate and testis [77]. OAT1 (SLC22A6), OAT2 (SLC22A7) and OAT3 (SLC22A8) are located at the basolateral membrane of the renal proximal tubular cells, where they are involved in the secretion of drugs and toxins for subsequent elimination into urine [79]. In contrast, OAT4 (SLC22A11), OAT10 (SLC22A13) and urate transporter 1 (URAT1) (SLC22A12) are expressed at the apical membrane of the proximal tubular cells, and are involved in the reabsorption of substances from the tubular fluid [79]. OAT2, OAT5 (SLC22A10) and OAT7 (SLC22A9) are located at the sinusoidal membrane of hepatocytes and are involved in liver detoxification processes [80]. Other OATs have less pharmacological relevance, such as OAT6 (SLC22A20), which is mainly expressed in the olfactory mucosa, but not in the kidney and liver [81], and the SLC22A orphan (S22AO) (SLC22A24), the unkwown substrate transporter 6 (UST6) (SLC22A25) and organic cation transporter-like 2 (OCTL2) (SLC22A14) that are poorly known.

\subsection{Role of Organic Anion Transporters in Drug Disposition}

OAT1 plays an essential role in the renal elimination of a broad range of toxins, drugs such as angiotensin-converting-enzyme inhibitors such as captopril [82], angiotensin II receptor blockers, such as olmesartan [83], diuretics such as furosemide [84], numerous guanine-based antiviral drugs including acyclovir, adefovir, cidofovir, ganciclovir or tenofovir [85-88], cimetidine and ranitidine [89], and anti-cancer agents, such as methotrexate [90]. In addition, some drugs, such as probenecid [91,92] and nonsteroidal anti-inflammatory drugs (NSAIDs) $[91,93,94]$ bind to OAT1, but cannot be translocated, thus blocking the secretion of another substrates of this transporter. Inhibition of OAT1-mediated renal anion secretion could be used to induce beneficial drug-drug interactions to either enhance activity of antibiotics or reduce renal accumulation and nephrotoxicity of certain antiviral drugs $[95,96]$. Thus, the co-administration of probenecid with cidofovir has been suggested to protect patients against cidofovir-induced nephrotoxicity, which is associated to excessive drug accumulation in renal proximal tubule cells [95].

OAT2 transport a variety of endogenous organic anions including prostaglandin $\mathrm{E}_{2}$, $\alpha$-ketoglutarate and cAMP $[97,98]$. Owing to its expression in both liver and kidney, and its ability to transport and hence affect the disposition of a wide variety of pharmacologically active agents, OAT2 is an important determinant in drug disposition. Thus, several antineoplastic drugs interfere with OAT2-mediated transport, whereas others such as methotrexate [97] or irinotecan [99] are substrates of this transporter. Controversial data regarding OAT2-mediated 5-fluorouracil (5-FU) transport have been reported $[99,100]$. In metastatic colorectal cancer, high expression of OAT2 seems to be a predictor of effectiveness of 5-FU-based chemotherapeutic regimens such as FOLFOX (5-FU/leucovorin/oxaliplatin) [101]. Acyclovir, ganciclovir and penciclovir are also substrates of OAT2 [86]. This also mediates the hepatic uptake of entecavir, an essential nucleoside analogue used in chronic hepatitis B treatment, playing an important role in the mechanisms underlying the efficacy of antiviral treatment. OAT2 is also involved in the transport of cimetidine and ranitidine [102] and some antibiotics, such as erythromycin [103] and tetracycline [104]. In general, NSAIDs are inhibitors of OAT2, but are not translocated [105], except for diclofenac, which has been reported to behave as a specific OAT2 substrate [106]. In addition, several diuretics inhibit OAT2 [84], but whether they are also translocated by this carrier is unknown. 
OAT3 is another important mechanism for urinary excretion of circulating anionic drugs and their metabolites. The substrate specificities of both transporters are partly overlapped, but not identical. In general, substrates of OAT3 are bulkier and more lipophilic than those of OAT1. OAT3 can transport zidovudine [107], cimetidine [102], diuretics, such as bumetanide or furosemide [84], antibiotics, including several cephalosporins [82], ciprofloxacin [108,109] and benzylpenicillin [110], statins, such as rosuvastatin [111] and pravastatin [112], and methotrexate [113]. OAT3 also shares with OAT1 many inhibitors, such as NSAIDs [114-116], ciprofloxacin [117], probenecid [116] or the integrase inhibitor cabotegravir [118]. Although this protein does not translocate them, they are frequently the cause of drug-drug interactions. Studies on Oat1 and Oat3 knockout animals have revealed a whole new range of endogenous substrates, which suggests that there is less overlap between Oat1 and Oat3 specificity (at least for metabolites) than previously thought $[119,120]$.

Estrone-sulfate is the prototypical substrate of OAT4, but this carrier can also transport other sulfate steroids such as dehydroepiandrosterone sulfate and the purine metabolite urate [121]. Owing to its location, OAT4 can either take up drugs from the tubular fluid or secrete them into urine. Well characterized OAT4 substrates include zidovudine [88], the antibiotic tetracycline [88], methotrexate [113], the NSAIDs ketoprofen and salicylate [93] and the diuretic bumetanide [84]. Other diuretics, such as hydrochlorothiazide and torsemide have been reported to trans-stimulate OAT4-mediated transport, suggesting that they can also be translocated [122]. Thus, OAT4-mediated efflux of some diuretic drugs increases urate reabsorption by the kidney leading to hyperuricemia [122].

There is little information available on the physiological role and the pharmacological impact of OAT5. A few drugs have been tested for potential OAT5-mediated transport and all of them have been found to act as inhibitors of this carrier [123].

OAT6 is a multi-specific organic anion transporter preferentially expressed in nasal epithelial cells [81] able to interact with a variety of small-molecule organic anions of physiological significance, among them the odorant molecules constitute the best ligands of this transporter [124]. Regarding its ability to transport drugs, OAT6 has been reported to mediate the uptake of the tyrosine kinase inhibitor sorafenib in human epidermal keratinocytes [125]. This suggests that OAT6 could be involved in the skin toxicity of this anticancer agent. Other therapeutic compounds, including antibiotics, antiviral agents and NSAIDs have been tested on murine Oat6, although none of them has turned out to be substrate of this transporter.

OAT7 transport sulfate steroids such as estrone-sulfate and dehydroepiandrosterone sulfate across the sinusoidal membrane of hepatocytes [126]. OAT7 may play a role in the hepatic uptake of pravastatin [127], the only drug identified as potential substrate of OAT7.

OAT10, previously known as ORCTL3 (organic cation transporter like 3), is an exchanger that takes up extracellular urate or nicotinate coupled to intracellular lactate, succinate, or glutathione [128]. Several diuretics have been reported to act as OAT10 inhibitors, without being themselves transported by OAT10. The immune suppressant cyclosporine A, in addition to inhibiting OAT10, trans-stimulate its function, suggesting that this compound is actually transported by OAT10 [128].

URAT1 is responsible for the reabsorption of uric acid from the kidney proximal tubules, thereby playing a key role in uric acid homeostasis [129]. URAT1 has limited substrate specificity, and no drugs transported by URAT1 have been identified. However, URAT1 has been proposed as a target of uricosuric drugs, such as 6-hydroxybenzbromarone, probenecid, indomethacin and salicylate, used to inhibit urate reabsorption [130]. Owing to nephrotoxicity of many anticancer regimens, urate handling is certainly important in oncologic patients undergoing chemotherapy. In this respect, SNPs in several OAT isoforms involved in urate transport [131,132] may favor the appearance of hyperuricemia during treatment.

\subsection{Impact of Genetic Variability in Pharmacokinetics}

Owing to the importance in drug disposition of OATs, the presence of genetic variants has often pharmacological consequences $[76,133]$ (Table 4). The available data regarding the functional 
relevance of mutations have permitted to distinguish three regions of interest: (i) the large extracellular loop; (ii) the central intracellular loop, highlighting its signature 'ESPXR', whose mutations can alter the interaction of the transporter with its substrates; and (iii) the transmembrane domains, especially TMD9 and TMD10, whose mutations may affect the interaction with plasma membrane components [3].

Table 4. Genetic variants in human organic anion transporters of the SLC22A family.

\begin{tabular}{|c|c|c|c|c|c|}
\hline $\begin{array}{l}\text { Transporter } \\
\text { (Gene) }\end{array}$ & $\begin{array}{c}\text { Genetic } \\
\text { Polymorphism }\end{array}$ & Amino Acid Change & $\begin{array}{l}\text { Effect on } \\
\text { Expression }\end{array}$ & Activity & Effect on Drug Disposition \\
\hline \multirow[t]{2}{*}{$\begin{array}{c}\text { OAT1 } \\
\text { (SLC22A6) }\end{array}$} & c.149G $>\mathrm{A} / \mathrm{C}$ & $\mathrm{R} 50 \mathrm{H}$ & $=$ & $\begin{array}{l}\text { Higher affinity for } \\
\text { adefovir, cidofovir and } \\
\text { tenofovir }\end{array}$ & No effect on renal clearance \\
\hline & c. $1361 \mathrm{G}>\mathrm{A}$ & R454Q & $=$ & Loss of activity & No effect on renal clearance \\
\hline \multirow{2}{*}{$\begin{array}{c}\text { OAT2 } \\
\text { (SLC22A7) }\end{array}$} & c.492_493insTCCCAG & E131_W132insSQ & $=$ & Lost & Not investigated \\
\hline & c. $1592+206 A>G$ & - & $\uparrow$ & Higher cell uptake & $\begin{array}{l}\text { Anthracycline-induced } \\
\text { cardiotoxicity and severe } \\
\text { toxicity to capecitabine }\end{array}$ \\
\hline \multirow{5}{*}{$\begin{array}{c}\text { OAT3 } \\
\text { (SLC22A8) }\end{array}$} & c. $445 \mathrm{C}>\mathrm{A}$ & R149S & $=$ & Lost & \multirow{5}{*}{$\begin{array}{c}\text { Not investigated } \\
\text { Not investigated } \\
\text { Not investigated } \\
\text { Not investigated } \\
\text { Lower renal clearance of } \\
\text { cefotaxime }\end{array}$} \\
\hline & c. $715 \mathrm{C}>\mathrm{T}$ & N239X & $=$ & Lost & \\
\hline & c. $779 \mathrm{~T}>\mathrm{G}$ & $\mathrm{I} 260 \mathrm{R}$ & $=$ & Lost & \\
\hline & c. $829 \mathrm{C}>\mathrm{T}$ & $\mathrm{R} 277 \mathrm{~W}$ & $=$ & Reduced & \\
\hline & c. $913 \mathrm{~A}>\mathrm{T}$ & $\mathrm{I} 305 \mathrm{~F}$ & $=$ & Reduced & \\
\hline \multirow{4}{*}{$\begin{array}{c}\text { OAT4 } \\
(\mathrm{SLC} 22 \mathrm{~A} 11)\end{array}$} & c. $86 \mathrm{~T}>\mathrm{C}$ & L29P & $=$ & & \multirow{4}{*}{$\begin{array}{l}\text { Lower renal clearance of } \\
\text { torsemide }\end{array}$} \\
\hline & c. $142 \mathrm{C}>\mathrm{T}$ & R48Y & $=$ & Reduced & \\
\hline & c. $464 \mathrm{~T}>\mathrm{G}$ & V155G & $=$ & Reduced & \\
\hline & c. $1175 \mathrm{C}>\mathrm{T}$ & T392I & $=$ & Reduced & \\
\hline \multirow{4}{*}{$\begin{array}{c}\text { OAT7 } \\
\text { (SLC22A9) }\end{array}$} & c. $268 \mathrm{C}>\mathrm{T}$ & R90C & $=$ & Reduced & \multirow{4}{*}{$\begin{array}{c}\text { Reduced hepatic uptake of } \\
\text { pravastatin }\end{array}$} \\
\hline & c. $1298 \mathrm{C}>\mathrm{G}$ & T433R & $=$ & Reduced & \\
\hline & c. $1298 \mathrm{C}>\mathrm{T}$ & $\mathrm{T} 433 \mathrm{M}$ & $=$ & Reduced & \\
\hline & c. $1437 \mathrm{~A}>\mathrm{G}$ & $\mathrm{I} 479 \mathrm{M}$ & $=$ & Reduced & \\
\hline \multirow{11}{*}{$\begin{array}{c}\text { URAT1 } \\
\text { (SLC22A12) }\end{array}$} & c. $269 \mathrm{G}>\mathrm{A}$ & $\mathrm{R} 90 \mathrm{H}$ & $=$ & Lost & \multirow{11}{*}{$\begin{array}{l}\text { Lower renal clearance of } \\
\text { drugs substrates of } \\
\text { the transporter }\end{array}$} \\
\hline & c. $412 \mathrm{G}>\mathrm{A}$ & V138M & $=$ & Lost & \\
\hline & c. $490 \mathrm{G}>\mathrm{A}$ & G164S & $=$ & Reduced & \\
\hline & c. $650 \mathrm{C}>\mathrm{T}$ & $\mathrm{T} 217 \mathrm{M}$ & $=$ & Lost & \\
\hline & c. $774 \mathrm{G}>\mathrm{A}$ & W258X & $=$ & Lost & \\
\hline & c. $889 \mathrm{C}>\mathrm{T}$ & Q297X & $=$ & Lost & \\
\hline & c. $894 \mathrm{G}>\mathrm{T}$ & E298D & $=$ & Lost & \\
\hline & c. $1145 \mathrm{~A}>\mathrm{T}$ & Q382L & $=$ & Reduced & \\
\hline & c. $1289 \mathrm{~T}>\mathrm{C}$ & $\mathrm{M} 430 \mathrm{~T}$ & $=$ & Reduced & \\
\hline & c.1639_1643del & V547Kfs & $=$ & Lost & \\
\hline & $\mathrm{IVS} 2+1 \mathrm{G}>\mathrm{A}$ & - & $\begin{array}{l}\text { Aberrant } \\
\text { splicing }\end{array}$ & Lost & \\
\hline
\end{tabular}

OAT1 and OAT2 have low genetic variability, which may be due to strong negative selection related to the important physiological role played by these carriers [134,135]. Polymorphisms found in the coding region of both OAT1 [134] and OAT2 [135] do not remarkably contribute to inter-individual variability in drug disposition. Although some of the mutations described in these transporters result in loss of activity when expressed in an in vitro system, no effect of these genetic variants in in vivo drug disposition has been found. This is probably due to the overlapping substrate specificity among SLC22 carriers. Thus, OAT1-R454Q variant shows a complete loss of activity when expressed in X. laevis oocytes, but no altered renal clearance of adefovir in patients carrying this genetic variant has been found [134]. Similarly, although the variant OAT1-R50H can transport the antivirals adefovir, cidofovir and tenofovir with higher affinity than the wild-type form [87], and therefore it is expected to increase the uptake by epithelial cells of proximal tubules, nephrotoxicity induced by these antiviral drugs is not higher in patients carrying this SNP [134].

An OAT2 splice variant containing an additional nucleotide sequence of the intron 1 (TCCCAG) between exons 1 and 2 of the OAT2 ORF has been detected in healthy liver, kidney and pancreas at approximately the same proportion of expression as the wild-type transporter [136]. The peptide encoded by the spliced variant contains two additional amino acids, Ser and Gln, and is not inserted at the plasma membrane, remaining intracellularly and consequently lacks transport activity [136]. Changes in the proportion of expression between the inactive variant and the wild-type form 
under physiological and pathological circumstances and its impact in pharmacology have not been elucidated yet.

At least 10 missense mutations in SLC22A8 gene have been found [137]. Among them, OAT3-R277W and OAT3-I305F variants that affect the central intracellular loop of the protein result in reduced ability to transport OAT3 substrates, such as estrone-3-sulfate and cimetidine [137]. OAT3 activity was completely abolished in OAT3-I260R variant [137]. Clinical studies of the repercussions of these mutations have only been carried out with patients bearing OAT3-I305F variant, who have a significantly lower renal clearance of cefotaxime compared to subjects who were homozygous for the reference allele [138]. Two other inactivating mutations affecting TMD3 (OAT3-R149S) and TMD6 (OAT3-N239X) have been described [137]. Although there is no clinical data available yet, these variants are probably associated with reduced renal elimination of drugs transported by OAT3 [139].

Among non-synonymous SNPs described in the SLC22A11 gene, OAT4-L29P, OAT4-R48Y, OAT4-V155G (which affect the large extracellular loop) and OAT4-T392I variants have a reduced transport activity [140]. A clinical study has shown that OAT4 genetic polymorphisms with impaired activity are associated to altered renal clearance of the diuretic torsemide [141].

Regarding SLC22A9 gene, three rare missense mutations have been found (c.268C $>\mathrm{T}$, c.1298C $>$ G/T, and c.1437A $>$ G), which do not affect the hepatic expression of OAT7, but decrease its activity when expressed in vitro, and may alter the in vivo disposition of pravastatin [127].

URAT1 is the only transporter of the SLC22 family whose mutations have been directly related to a disease. Inactivating mutations of URAT1 inhibit the renal reabsorption of urate and cause familial idiopathic hypouricemia [129]. Nonsense (c.774G $>$ A and c.889C $>$ T) and frameshift mutations (IVS2 + 1G>A and c.1639_1643delGTCCT) in the SLC22A12 gene, which abolish the transport activity, and missense mutations (c.269G>A, c.412G >A, c.490G>A, c.650C > T, c.1145A>T, and c.1289T>C), which reduce its activity, have been described [142]. These variants may decrease renal secretion of drugs transported by URAT1 and, therefore, increase its clearance. However, to date there is no affected drug identified [130].

Usually, the presence of polymorphisms in non-coding regions of the SLC22 genes is not an important factor affecting the expression of these proteins and their transport activity $[143,144]$. However, a mutation found in the 3'-UTR region of SLC22A7 gene (c.1592 + 206A>G) results in OAT2 up-regulation and hence, increased uptake of drugs, such as anthracyclines and 5-FU. Consequently, the presence of this mutation has been associated with anthracycline-induced cardiotoxicity [145] and severe toxicity to the 5-FU prodrug capecitabine [146].

\section{SLC22 Genetic Heterogeneity in Cancer Pharmacology}

The set of transformations suffered by cells during oncogenic phase is accompanied by modifications in cell metabolism that also affect the expression of drug transporters, which may have an important impact on the effectiveness of chemotherapy [147]. The expression of members of the SLC22 family in different types of tumors has been well characterized [77]. Pharmacogenomic studies have shown that polymorphisms in genes related to drug transport through the SLC22 family have a considerable effect on the response to different antitumor drugs [148]. Moreover, the allelic variants found in members of the SLC22 family of transporters are associated with various modifications that determine aspects of the disease, such as tumor progression [149].

The mutations described in the SLC22A1 gene affect all regions of this gene. Restricting the analysis to the coding sequence, one deletion of three base pairs (M420del), eight nonsense mutations, and 49 missense mutations have been reported [58,150,151]. Under physiological circumstances, variants with reduced transport function have substitutions in amino acids that cause more drastic structural changes, being evolutionarily less favorable than the variants with conserved function [152]. However, the situation is the opposite in cancer cells exposed to chemotherapeutic challenge. Because several antitumor drugs, such as irinotecan, mitoxantrone, oxaliplatin, paclitaxel, imatinib and sorafenib have been described as OCT1 substrates [153], the expression level and 
the activity of this transporter may play a key role for chemotherapeutic response to these drugs. In these sense, in patients with chronic myeloid leukemia (CML), homozygosis for the variants rs4646278 (R287G/W, c.859C >G) and rs4646277 (P283L, c.848C $>$ T) have been described together with three low frequency allelic variants: rs12208357 (R61C, c.181C >T), rs72552763 (M420del, c.1260_1262delGAT) and $r 5683369$ (L160F, c.480G>C). CML patients carrying the OCT1 c.480G allelic variant have lower clearance of imatinib than patients homozygous for the c.480C allelic variant [154]. However, clinical data indicates that CML patients with OCT1 polymorphisms that were negatively related with imatinib efficacy had no impact on nilotinib efficacy or toxicity [155].

Two OCT1 variants (A99T and G174S) have been identified in patients with chronic lymphocytic leukemia (CLL). Genetic heterogeneity appears for the most common variants of SLC22A1 in patients with CLL except for the small increase in the allelic frequencies of relatively rare variants such as G38D and P341L [156].

In liver tumors, the expression levels of OCT1 may be important for the response of these patients to sorafenib, the only drug moderately useful in the treatment of hepatocellular carcinoma. So, the expression levels of OCT1 have been described to be downregulated in liver cancer, and also several, variants of OCT1 have been identified in these tumors, including SNPs and splicing variants [151]. Among these SNPs, some of them have been reported in in vitro studies to attenuate sorafenib-induced toxicity; as an example of OCT1 SNPs related with lower sorafenib transport are OCT1 R61S fs*10 and C88A fs*16 that produce a shift in the open reading frame that result in non-functional truncated proteins. In detail, R61S fs*10 is a genetic variant caused by a frameshift mutation originated by deletion of two nucleotides and the insertion of one (c.181delCGinsT), that generates a change in the amino acid 61 (arginine changes to serine) and also introduces a stop codon that makes that the protein ends 10 amino acids after of position 61 , making a resulting protein of 71 instead of 554 amino acid that form the wild type OCT1. Similarly, C88A fs*16 is caused by a deletion of one nucleotide (c.262delT), that generates a change in the amino acid at the position 88 , and also introduces a stop codon that makes that the resultant protein contain only 104 amino acids. Short and non-functional OCT1 variants have also been detected in glioma [58].

Loss of expression of OCT2 at the transcriptional and protein level in renal carcinoma cells has been reported [147]. In vitro studies have indicated that the repression of OCT2 is an important factor in the resistance to oxaliplatin in renal carcinoma cells, and a non-synonymous SNP (rs316019) in the SLC22A2 gene has been associated with a decrease in cisplatin nephrotoxicity in patients with renal carcinoma [157]. SNPs in OCT2 in combination with ENT1 and MATE1 variants may serve as predictive and prognostic markers in refractory metastasis of colorectal cancer treated with TAS-102 [158].

OCT3 SNPs have been related to the level of SLC22A3 mRNA and the risk of prostate, colorectal cancer and other diseases [159]. Thus, in colorectal cancer, an OCT3 variant located at 6q26-q27 ( $r$ s7758229; c.975 + 8374G $>\mathrm{A}$ in the non-coding region of $S L C 22 A 3$ ), has been associated with distal tumors [160]. The polymorphic variant $r s 9364554(\mathrm{c} .582+1786 \mathrm{C}>\mathrm{T})$ is associated with decreased OCT3 expression in prostate cancer [161], whereas the common variant g.-2G $>A$ ( $r s 555754$ ) has been associated with a higher level of OCT3 expression [159].

A relationship between variants of OCTN transporters and the efficacy of imatinib has been suggested to play an important role in the efficacy of this drug in adjuvant therapy [149]. Among patients with gastrointestinal stromal tumors treated with imatinib, the time to progression period significantly improves in carriers of the $\mathrm{C}$ allele of the variant of OCTN1 rs1050152 (L503F, c.1507C > T) as well as in carriers of the minor alleles of the variants of OCTN2 $r s 2631367$ (c.-207C >G) and $r s 2631372$ (c.-2087G >C), both localized in the promoter, suggesting that the activities of OCTN1 and OCTN2 may be predictors of efficacy to chemotherapy with imatinib [147].

Pharmacogenetic studies have shown that polymorphisms in genes related to metabolism and drug transport can have a significant effect on the response to imatinib in patients with CML. Thus, an important association between the polymorphism rs1050152 of OCTN2 and the molecular 
response to imatinib has been found [162]. Variants $r s 2631367$ (L503F, c.1507C $>\mathrm{T}$ ) and $r s 2631372$ (c.-2087G $>$ C) in OCTN2 are associated with an improvement in time to progression in CML [162].

There is a surprising high promiscuity in the profile of endogenous and xenobiotic compounds transported by the different OATs, so it is critical to understand the mechanisms that regulate the expression and function of OATs by genetic and epigenetic factors [163]. In addition, inter-individual variability among patients and tumors, which can markedly affect the outcome of chemotherapy, is largely dependent upon SNPs occurrence [164,165]. Thus, OAT2, which is highly express in liver, play a role in the uptake and subsequent metabolism of many antineoplastic drugs, such as 5-FU, which is used in colorectal and pancreatic cancer therapy.

In addition to SNPs, epigenetic mechanisms have been related with changes in the expression levels of SLC22 genes in different tumors. Thus, hypermethylation has been proposed as an important event related with a decrease in the expression of several SLC22 genes. For instance, OCT1 down-regulation in hepatocellular carcinoma has been related with an enhanced methylation of the promoter [166]. Similarly, methylation is also involved in the inhibition of OCT2 transcription. Consistently, epigenetic activation of OCT2 by decitabine, a demethylating agent, has been observed in renal carcinoma cells sensitive to oxaliplatin in a sequential and combinatorial therapy carried out in vitro and in a xenograft model [157]. Hypermethylation of the promoter region of SLC22A3 gene is an important mechanism accounting for reduced OCT3 expression in prostate cancer [159].

\section{Conclusions and Perspectives}

In the time of emerging personalized medicine, it is becoming more evident that there is a need of, not only understanding the mechanisms of action and the profile of substrate specificity characteristic of each transporter involved in drug disposition, but also identifying the genetic signature accounted for by the existence of polymorphisms that markedly determine the response of the patient to any given drug or combination of drugs. In this respect, the SLC22 family of transporters constitutes an important subject of interest for several reasons that have been reviewed here. In the near future, modern pharmacology will probably need to implement an analysis of expression levels and the detection of genetic variants regarding SLC22 transporters and other carriers playing a key role in drug disposition, such as members of the SLCO family of uptake transporters and ABC export pumps. One could expect this analysis to be performed before treatments, but in some cases this should be repeated during certain treatments, which will be most necessary in anticancer chemotherapy, due to the dynamic nature of the target tissue, in which both expression levels and mutation may undergo alterations as an individual cancer characteristic present before starting the treatment but that usually change during chemotherapy or even radiotherapy of the tumor.

Acknowledgments: This study was supported by the Carlos III Institute of Health, Spain (PI15/00179 and PI16/00598, co-funded by European Regional Development Fund/European Social Fund, "Investing in your future"), the Ministry of Science and Innovation, Spain (SAF2013-40620-R and SAF2016-75197-R), the "Junta de Castilla y León", Spain (SA015U13 and SA063P17), the "Fundación Mutua Madrileña", Spain (Call 2015), the "Fundación Samuel Solorzano", Spain (FS/7-2016; FS/8-2017 and FS/13-2017) and the "Fundación AECC", Spain (Call 2017). Our group is member of the Network for Cooperative Research on Membrane Transport Proteins (REIT) and belongs to the Centre for the Study of Liver and Gastrointestinal Diseases (CIBERehd) Carlos III Institute of Health, Spain.

Conflicts of Interest: The authors declare no conflicts of interest.

\section{References}

1. Nigam, S.K. The SLC22 transporter family: A paradigm for the impact of drug transporters on metabolic pathways, signaling, and disease. Annu. Rev. Pharmacol. Toxicol. 2018, 58, 663-687. [CrossRef] [PubMed]

2. Koepsell, H.; Endou, H. The SLC22 drug transporter family. Pflugers Arch. 2004, 447, 666-676. [CrossRef] [PubMed] 
3. Zhu, C.; Nigam, K.B.; Date, R.C.; Bush, K.T.; Springer, S.A.; Saier, M.H., Jr.; Wu, W.; Nigam, S.K. Evolutionary analysis and classification of OATs, OCTs, OCTNs, and other SLC22 transporters: Structure-function implications and analysis of sequence motifs. PLoS ONE 2015, 10, e0140569. [CrossRef] [PubMed]

4. Kaler, G.; Truong, D.M.; Khandelwal, A.; Nagle, M.; Eraly, S.A.; Swaan, P.W.; Nigam, S.K. Structural variation governs substrate specificity for organic anion transporter (OAT) homologs. Potential remote sensing by OAT family members. J. Biol. Chem. 2007, 282, 23841-23853. [CrossRef] [PubMed]

5. Chien, H.C.; Zur, A.A.; Maurer, T.S.; Yee, S.W.; Tolsma, J.; Jasper, P.; Scott, D.O.; Giacomini, K.M. Rapid method to determine intracellular drug concentrations in cellular uptake assays: Application to metformin in organic cation transporter 1-transfected human embryonic kidney 293 cells. Drug Metab. Dispos. 2016, 44, 356-364. [CrossRef] [PubMed]

6. Burckhardt, B.C.; Burckhardt, G. Transport of organic anions across the basolateral membrane of proximal tubule cells. Rev. Physiol. Biochem. Pharmacol. 2003, 146, 95-158. [PubMed]

7. Engstrom, K.; Ameer, S.; Bernaudat, L.; Drasch, G.; Baeuml, J.; Skerfving, S.; Bose-O’Reilly, S.; Broberg, K. Polymorphisms in genes encoding potential mercury transporters and urine mercury concentrations in populations exposed to mercury vapor from gold mining. Environ. Health Perspect. 2013, 121, 85-91. [PubMed]

8. Han, Y.F.; Fan, X.H.; Wang, X.J.; Sun, K.; Xue, H.; Li, W.J.; Wang, Y.B.; Chen, J.Z.; Zhen, Y.S.; Zhang, W.L.; et al. Association of intergenic polymorphism of organic anion transporter 1 and 3 genes with hypertension and blood pressure response to hydrochlorothiazide. Am. J. Hypertens. 2011, 24, 340-346. [CrossRef] [PubMed]

9. $\mathrm{Xu}$, G.; Bhatnagar, V.; Wen, G.; Hamilton, B.A.; Eraly, S.A.; Nigam, S.K. Analyses of coding region polymorphisms in apical and basolateral human organic anion transporter (OAT) genes [OAT1 (NKT), OAT2, OAT3, OAT4, URAT (RST)]. Kidney Int. 2005, 68, 1491-1499. [CrossRef] [PubMed]

10. Arimany-Nardi, C.; Koepsell, H.; Pastor-Anglada, M. Role of SLC22A1 polymorphic variants in drug disposition, therapeutic responses, and drug-drug interactions. Pharmacogenomics J. 2015, 15, 473-487. [CrossRef] [PubMed]

11. Koepsell, H. Polyspecific organic cation transporters: Their functions and interactions with drugs. Trends Pharmacol. Sci. 2004, 25, 375-381. [CrossRef] [PubMed]

12. Sala-Rabanal, M.; Li, D.C.; Dake, G.R.; Kurata, H.T.; Inyushin, M.; Skatchkov, S.N.; Nichols, C.G. Polyamine transport by the polyspecific organic cation transporters OCT1, OCT2, and OCT3. Mol. Pharm. 2013, 10, 1450-1458. [CrossRef] [PubMed]

13. Lemos, C.; Faria, A.; Meireles, M.; Martel, F.; Monteiro, R.; Calhau, C. Thiamine is a substrate of organic cation transporters in Caco-2 cells. Eur. J. Pharmacol. 2012, 682, 37-42. [CrossRef] [PubMed]

14. Gorboulev, V.; Ulzheimer, J.C.; Akhoundova, A.; Ulzheimer-Teuber, I.; Karbach, U.; Quester, S.; Baumann, C.; Lang, F.; Busch, A.E.; Koepsell, H. Cloning and characterization of two human polyspecific organic cation transporters. DNA Cell Biol. 1997, 16, 871-881. [CrossRef] [PubMed]

15. Koepsell, H.; Lips, K.; Volk, C. Polyspecific organic cation transporters: Structure, function, physiological roles, and biopharmaceutical implications. Pharm. Res. 2007, 24, 1227-1251. [CrossRef] [PubMed]

16. Kimura, H.; Takeda, M.; Narikawa, S.; Enomoto, A.; Ichida, K.; Endou, H. Human organic anion transporters and human organic cation transporters mediate renal transport of prostaglandins. J. Pharmacol. Exp. Ther. 2002, 301, 293-298. [CrossRef] [PubMed]

17. Motohashi, H.; Sakurai, Y.; Saito, H.; Masuda, S.; Urakami, Y.; Goto, M.; Fukatsu, A.; Ogawa, O.; Inui, K. Gene expression levels and immunolocalization of organic ion transporters in the human kidney. J. Am. Soc. Nephrol. 2002, 13, 866-874. [PubMed]

18. Busch, A.E.; Karbach, U.; Miska, D.; Gorboulev, V.; Akhoundova, A.; Volk, C.; Arndt, P.; Ulzheimer, J.C.; Sonders, M.S.; Baumann, C.; et al. Human neurons express the polyspecific cation transporter hOCT2, which translocates monoamine neurotransmitters, amantadine, and memantine. Mol. Pharmacol. 1998, 54, 342-352. [CrossRef] [PubMed]

19. Lips, K.S.; Volk, C.; Schmitt, B.M.; Pfeil, U.; Arndt, P.; Miska, D.; Ermert, L.; Kummer, W.; Koepsell, H. Polyspecific cation transporters mediate luminal release of acetylcholine from bronchial epithelium. Am. J. Respir. Cell Mol. Biol. 2005, 33, 79-88. [CrossRef] [PubMed]

20. Wu, X.; Huang, W.; Ganapathy, M.E.; Wang, H.; Kekuda, R.; Conway, S.J.; Leibach, F.H.; Ganapathy, V. Structure, function, and regional distribution of the organic cation transporter OCT3 in the kidney. Am. J. Physiol. Renal Physiol. 2000, 279, F449-F458. [CrossRef] [PubMed] 
21. Sata, R.; Ohtani, H.; Tsujimoto, M.; Murakami, H.; Koyabu, N.; Nakamura, T.; Uchiumi, T.; Kuwano, M.; Nagata, H.; Tsukimori, K.; et al. Functional analysis of organic cation transporter 3 expressed in human placenta. J. Pharmacol. Exp. Ther. 2005, 315, 888-895. [CrossRef] [PubMed]

22. Lee, N.; Duan, H.; Hebert, M.F.; Liang, C.J.; Rice, K.M.; Wang, J. Taste of a pill: Organic cation transporter-3 (OCT3) mediates metformin accumulation and secretion in salivary glands. J. Biol. Chem. 2014, 289, 27055-27064. [CrossRef] [PubMed]

23. Breining, P.; Pedersen, S.B.; Pikelis, A.; Rolighed, L.; Sundelin, E.I.O.; Jessen, N.; Richelsen, B. High expression of organic cation transporter 3 in human bat-like adipocytes. Implications for extraneuronal norepinephrine uptake. Mol. Cell. Endocrinol. 2017, 443, 15-22. [CrossRef] [PubMed]

24. Tamai, I.; Yabuuchi, H.; Nezu, J.; Sai, Y.; Oku, A.; Shimane, M.; Tsuji, A. Cloning and characterization of a novel human pH-dependent organic cation transporter, OCTN1. FEBS Lett. 1997, 419, 107-111. [CrossRef]

25. Garrett, Q.; Xu, S.; Simmons, P.A.; Vehige, J.; Flanagan, J.L.; Willcox, M.D. Expression and localization of carnitine/organic cation transporter OCTN1 and OCTN2 in ocular epithelium. Investig. Ophthalmol. Vis. Sci. 2008, 49, 4844-4849. [CrossRef] [PubMed]

26. Grundemann, D.; Harlfinger, S.; Golz, S.; Geerts, A.; Lazar, A.; Berkels, R.; Jung, N.; Rubbert, A.; Schomig, E. Discovery of the ergothioneine transporter. Proc. Natl. Acad. Sci. USA 2005, 102, 5256-5261. [CrossRef] [PubMed]

27. Pochini, L.; Scalise, M.; Galluccio, M.; Pani, G.; Siminovitch, K.A.; Indiveri, C. The human OCTN1 (SLC22A4) reconstituted in liposomes catalyzes acetylcholine transport which is defective in the mutant L503F associated to the Crohn's disease. Biochim. Biophys. Acta 2012, 1818, 559-565. [CrossRef] [PubMed]

28. Lamhonwah, A.M.; Tein, I. Novel localization of OCTN1, an organic cation/carnitine transporter, to mammalian mitochondria. Biochem. Biophys. Res. Commun. 2006, 345, 1315-1325. [CrossRef] [PubMed]

29. Tamai, I.; Ohashi, R.; Nezu, J.; Yabuuchi, H.; Oku, A.; Shimane, M.; Sai, Y.; Tsuji, A. Molecular and functional identification of sodium ion-dependent, high affinity human carnitine transporter OCTN2. J. Biol. Chem. 1998, 273, 20378-20382. [CrossRef] [PubMed]

30. Wu, X.; Huang, W.; Prasad, P.D.; Seth, P.; Rajan, D.P.; Leibach, F.H.; Chen, J.; Conway, S.J.; Ganapathy, V. Functional characteristics and tissue distribution pattern of organic cation transporter 2 (OCTN2), an organic cation/carnitine transporter. J. Pharmacol. Exp. Ther. 1999, 290, 1482-1492. [PubMed]

31. Lamhonwah, A.M.; Skaug, J.; Scherer, S.W.; Tein, I. A third human carnitine/organic cation transporter (OCTN3) as a candidate for the 5q31 Crohn's disease locus (IBD5). Biochem. Biophys. Res. Commun. 2003, 301, 98-101. [CrossRef]

32. Lamhonwah, A.M.; Ackerley, C.A.; Tilups, A.; Edwards, V.D.; Wanders, R.J.; Tein, I. OCTN3 is a mammalian peroxisomal membrane carnitine transporter. Biochem. Biophys. Res. Commun. 2005, 338, 1966-1972. [CrossRef] [PubMed]

33. Gong, S.; Lu, X.; Xu, Y.; Swiderski, C.F.; Jordan, C.T.; Moscow, J.A. Identification of OCT6 as a novel organic cation transporter preferentially expressed in hematopoietic cells and leukemias. Exp. Hematol. 2002, 30, 1162-1169. [CrossRef]

34. Giacomini, K.M.; Huang, S.M.; Tweedie, D.J.; Benet, L.Z.; Brouwer, K.L.; Chu, X.; Dahlin, A.; Evers, R.; Fischer, V.; Hillgren, K.M.; et al. Membrane transporters in drug development. Nat. Rev. Drug Discov. 2010, 9, 215-236. [PubMed]

35. Wang, D.S.; Jonker, J.W.; Kato, Y.; Kusuhara, H.; Schinkel, A.H.; Sugiyama, Y. Involvement of organic cation transporter 1 in hepatic and intestinal distribution of metformin. J. Pharmacol. Exp. Ther. 2002, 302, 510-515. [CrossRef] [PubMed]

36. Jung, N.; Lehmann, C.; Rubbert, A.; Knispel, M.; Hartmann, P.; van Lunzen, J.; Stellbrink, H.J.; Faetkenheuer, G.; Taubert, D. Relevance of the organic cation transporters 1 and 2 for antiretroviral drug therapy in human immunodeficiency virus infection. Drug Metab. Dispos. 2008, 36, 1616-1623. [CrossRef] [PubMed]

37. Tzvetkov, M.V.; Saadatmand, A.R.; Lotsch, J.; Tegeder, I.; Stingl, J.C.; Brockmoller, J. Genetically polymorphic OCT1: Another piece in the puzzle of the variable pharmacokinetics and pharmacodynamics of the opioidergic drug tramadol. Clin. Pharmacol. Ther. 2011, 90, 143-150. [CrossRef] [PubMed] 
38. Matthaei, J.; Kuron, D.; Faltraco, F.; Knoch, T.; Dos Santos Pereira, J.N.; Abu Abed, M.; Prukop, T.; Brockmoller, J.; Tzvetkov, M.V. OCT1 mediates hepatic uptake of sumatriptan and loss-of-function oct1 polymorphisms affect sumatriptan pharmacokinetics. Clin. Pharmacol. Ther. 2016, 99, 633-641. [CrossRef] [PubMed]

39. Tzvetkov, M.V.; Saadatmand, A.R.; Bokelmann, K.; Meineke, I.; Kaiser, R.; Brockmoller, J. Effects of OCT1 polymorphisms on the cellular uptake, plasma concentrations and efficacy of the 5-HT(3) antagonists tropisetron and ondansetron. Pharmacogenomics J. 2012, 12, 22-29. [CrossRef] [PubMed]

40. Tzvetkov, M.V.; dos Santos Pereira, J.N.; Meineke, I.; Saadatmand, A.R.; Stingl, J.C.; Brockmoller, J. Morphine is a substrate of the organic cation transporter OCT1 and polymorphisms in OCT1 gene affect morphine pharmacokinetics after codeine administration. Biochem. Pharmacol. 2013, 86, 666-678. [CrossRef] [PubMed]

41. Bourdet, D.L.; Pritchard, J.B.; Thakker, D.R. Differential substrate and inhibitory activities of ranitidine and famotidine toward human organic cation transporter 1 (hOCT1; SLC22A1), hOCT2 (SLC22A2), and hOCT3 (SLC22A3). J. Pharmacol. Exp. Ther. 2005, 315, 1288-1297. [CrossRef] [PubMed]

42. Umehara, K.I.; Iwatsubo, T.; Noguchi, K.; Kamimura, H. Functional involvement of organic cation transporter1 (OCT1/Oct1) in the hepatic uptake of organic cations in humans and rats. Xenobiotica 2007, 37, 818-831. [CrossRef] [PubMed]

43. Van Montfoort, J.E.; Muller, M.; Groothuis, G.M.; Meijer, D.K.; Koepsell, H.; Meier, P.J. Comparison of “Type $\mathrm{I}^{\prime}$ and "Type II" organic cation transport by organic cation transporters and organic anion-transporting polypeptides. J. Pharmacol. Exp. Ther. 2001, 298, 110-115. [PubMed]

44. Mulgaonkar, A.; Venitz, J.; Grundemann, D.; Sweet, D.H. Human organic cation transporters 1 (SLC22A1), 2 (SLC22A2), and 3 (SLC22A3) as disposition pathways for fluoroquinolone antimicrobials. Antimicrob. Agents Chemother. 2013, 57, 2705-2711. [CrossRef] [PubMed]

45. Dickens, D.; Owen, A.; Alfirevic, A.; Giannoudis, A.; Davies, A.; Weksler, B.; Romero, I.A.; Couraud, P.O.; Pirmohamed, M. Lamotrigine is a substrate for OCT1 in brain endothelial cells. Biochem. Pharmacol. 2012, 83, 805-814. [CrossRef] [PubMed]

46. Kimura, N.; Okuda, M.; Inui, K. Metformin transport by renal basolateral organic cation transporter hOCT2. Pharm. Res. 2005, 22, 255-259. [CrossRef] [PubMed]

47. Li, L.; Weng, Y.; Wang, W.; Bai, M.; Lei, H.; Zhou, H.; Jiang, H. Multiple organic cation transporters contribute to the renal transport of sulpiride. Biopharm. Drug Dispos. 2017, 38, 526-534. [CrossRef] [PubMed]

48. Van der Velden, M.; Bilos, A.; van den Heuvel, J.; Rijpma, S.R.; Hurkmans, E.G.E.; Sauerwein, R.W.; Russel, F.G.M.; Koenderink, J.B. Proguanil and cycloguanil are organic cation transporter and multidrug and toxin extrusion substrates. Malar. J. 2017, 16, 422. [CrossRef] [PubMed]

49. Yang, X.; Ma, Z.; Zhou, S.; Weng, Y.; Lei, H.; Zeng, S.; Li, L.; Jiang, H. Multiple drug transporters are involved in renal secretion of entecavir. Antimicrob. Agents Chemother. 2016, 60, 6260-6270. [CrossRef] [PubMed]

50. Yin, J.; Duan, H.; Shirasaka, Y.; Prasad, B.; Wang, J. Atenolol renal secretion is mediated by human organic cation transporter 2 and multidrug and toxin extrusion proteins. Drug Metab. Dispos. 2015, 43, 1872-1881. [CrossRef] [PubMed]

51. Minematsu, T.; Iwai, M.; Umehara, K.; Usui, T.; Kamimura, H. Characterization of human organic cation transporter 1 (OCT1/SLC22A1)- and oct2 (SLC22A2)-mediated transport of 1-(2-methoxyethyl)-2-methyl-4,9-dioxo-3-(pyrazin-2-ylmethyl)-4,9-dihydro-1H-naphtho[2,3-d]imidazolium bromide (YM155 monobromide), a novel small molecule survivin suppressant. Drug Metab. Dispos. 2010, 38, 1-4. [PubMed]

52. Mulgaonkar, A.; Venitz, J.; Sweet, D.H. Fluoroquinolone disposition: Identification of the contribution of renal secretory and reabsorptive drug transporters. Expert Opin. Drug Metab. Toxicol. 2012, 8, 553-569. [CrossRef] [PubMed]

53. Chen, E.C.; Liang, X.; Yee, S.W.; Geier, E.G.; Stocker, S.L.; Chen, L.; Giacomini, K.M. Targeted disruption of organic cation transporter 3 attenuates the pharmacologic response to metformin. Mol. Pharmacol. 2015, 88, 75-83. [CrossRef] [PubMed]

54. Xu, F.; Li, Z.; Zheng, J.; Gee Cheung, F.S.; Chan, T.; Zhu, L.; Zhuge, H.; Zhou, F. The inhibitory effects of the bioactive components isolated from Scutellaria baicalensis on the cellular uptake mediated by the essential solute carrier transporters. J. Pharm. Sci. 2013, 102, 4205-4211. [CrossRef] [PubMed] 
55. Chiappori, A.; Folli, C.; Riccio, A.M.; Caci, E.; Descalzi, D.; De Ferrari, L.; Ingrassia, E.; Nicolini, G.; Canonica, G.W. Salbutamol: How does it enter smooth muscle cells? Int. J. Immunopathol. Pharmacol. 2012, 25, 541-546. [CrossRef] [PubMed]

56. Urban, T.J.; Brown, C.; Castro, R.A.; Shah, N.; Mercer, R.; Huang, Y.; Brett, C.M.; Burchard, E.G.; Giacomini, K.M. Effects of genetic variation in the novel organic cation transporter, OCTN1, on the renal clearance of gabapentin. Clin. Pharmacol. Ther. 2008, 83, 416-421. [CrossRef] [PubMed]

57. Oguri, T.; Kunii, E.; Fukuda, S.; Sone, K.; Uemura, T.; Takakuwa, O.; Kanemitsu, Y.; Ohkubo, H.; Takemura, M.; Maeno, K.; et al. Organic cation transporter 6 directly confers resistance to anticancer platinum drugs. Biomed. Rep. 2016, 5, 639-643. [CrossRef] [PubMed]

58. Hayer, M.; Bonisch, H.; Bruss, M. Molecular cloning, functional characterization and genomic organization of four alternatively spliced isoforms of the human organic cation transporter 1 (hOCT1/SLC22A1). Ann. Hum. Genet. 1999, 63, 473-482. [CrossRef] [PubMed]

59. Shu, Y.; Sheardown, S.A.; Brown, C.; Owen, R.P.; Zhang, S.; Castro, R.A.; Ianculescu, A.G.; Yue, L.; Lo, J.C.; Burchard, E.G.; et al. Effect of genetic variation in the organic cation transporter 1 (OCT1) on metformin action. J. Clin. Investig. 2007, 117, 1422-1431. [CrossRef] [PubMed]

60. Becker, M.L.; Visser, L.E.; van Schaik, R.H.; Hofman, A.; Uitterlinden, A.G.; Stricker, B.H. Genetic variation in the organic cation transporter 1 is associated with metformin response in patients with diabetes mellitus. Pharmacogenomics J. 2009, 9, 242-247. [CrossRef] [PubMed]

61. Tarasova, L.; Kalnina, I.; Geldnere, K.; Bumbure, A.; Ritenberga, R.; Nikitina-Zake, L.; Fridmanis, D.; Vaivade, I.; Pirags, V.; Klovins, J. Association of genetic variation in the organic cation transporters OCT1, OCT2 and multidrug and toxin extrusion 1 transporter protein genes with the gastrointestinal side effects and lower BMI in metformin-treated type 2 diabetes patients. Pharmacogenetics Genom. 2012, 22, 659-666. [CrossRef] [PubMed]

62. Venkatasubramanian, R.; Fukuda, T.; Niu, J.; Mizuno, T.; Chidambaran, V.; Vinks, A.A.; Sadhasivam, S. ABCC3 and OCT1 genotypes influence pharmacokinetics of morphine in children. Pharmacogenomics 2014, 15, 1297-1309. [CrossRef] [PubMed]

63. Fukuda, T.; Chidambaran, V.; Mizuno, T.; Venkatasubramanian, R.; Ngamprasertwong, P.; Olbrecht, V.; Esslinger, H.R.; Vinks, A.A.; Sadhasivam, S. OCT1 genetic variants influence the pharmacokinetics of morphine in children. Pharmacogenomics 2013, 14, 1141-1151. [CrossRef] [PubMed]

64. Becker, M.L.; Visser, L.E.; van Schaik, R.H.; Hofman, A.; Uitterlinden, A.G.; Stricker, B.H. OCT1 polymorphism is associated with response and survival time in anti-Parkinsonian drug users. Neurogenetics 2011, 12, 79-82. [CrossRef] [PubMed]

65. Martel, F.; Grundemann, D.; Calhau, C.; Schomig, E. Apical uptake of organic cations by human intestinal Caco-2 cells: Putative involvement of ASF transporters. Naunyn Schmiedebergs Arch. Pharmacol. 2001, 363, 40-49. [CrossRef] [PubMed]

66. Shen, C.H.; Zhang, Y.X.; Lu, R.Y.; Jin, B.; Wang, S.; Liu, Z.R.; Tang, Y.L.; Ding, M.P. Specific OCT1 and ABCG2 polymorphisms are associated with lamotrigine concentrations in Chinese patients with epilepsy. Epilepsy Res. 2016, 127, 186-190. [CrossRef] [PubMed]

67. Dos Santos Pereira, J.N.; Tadjerpisheh, S.; Abu Abed, M.; Saadatmand, A.R.; Weksler, B.; Romero, I.A.; Couraud, P.O.; Brockmoller, J.; Tzvetkov, M.V. The poorly membrane permeable antipsychotic drugs amisulpride and sulpiride are substrates of the organic cation transporters from the SLC22 family. AAPS J. 2014, 16, 1247-1258. [CrossRef] [PubMed]

68. Choi, M.K.; Song, I.S. Genetic variants of organic cation transporter 1 (OCT1) and OCT2 significantly reduce lamivudine uptake. Biopharm. Drug Dispos. 2012, 33, 170-178. [CrossRef] [PubMed]

69. Saadatmand, A.R.; Tadjerpisheh, S.; Brockmoller, J.; Tzvetkov, M.V. The prototypic pharmacogenetic drug debrisoquine is a substrate of the genetically polymorphic organic cation transporter OCT1. Biochem. Pharmacol. 2012, 83, 1427-1434. [CrossRef] [PubMed]

70. Song, I.S.; Shin, H.J.; Shim, E.J.; Jung, I.S.; Kim, W.Y.; Shon, J.H.; Shin, J.G. Genetic variants of the organic cation transporter 2 influence the disposition of metformin. Clin. Pharmacol. Ther. 2008, 84, 559-562. [CrossRef] [PubMed]

71. Urakami, Y.; Akazawa, M.; Saito, H.; Okuda, M.; Inui, K. cDNA cloning, functional characterization, and tissue distribution of an alternatively spliced variant of organic cation transporter hOCT2 predominantly expressed in the human kidney. J. Am. Soc. Nephrol. 2002, 13, 1703-1710. [CrossRef] [PubMed] 
72. Sakata, T.; Anzai, N.; Kimura, T.; Miura, D.; Fukutomi, T.; Takeda, M.; Sakurai, H.; Endou, H. Functional analysis of human organic cation transporter OCT3 (SLC22A3) polymorphisms. J. Pharmacol. Sci. 2010, 113, 263-266. [CrossRef] [PubMed]

73. Kawasaki, Y.; Kato, Y.; Sai, Y.; Tsuji, A. Functional characterization of human organic cation transporter OCTN1 single nucleotide polymorphisms in the Japanese population. J. Pharm. Sci. 2004, 93, 2920-2926. [CrossRef] [PubMed]

74. Urban, T.J.; Yang, C.; Lagpacan, L.L.; Brown, C.; Castro, R.A.; Taylor, T.R.; Huang, C.C.; Stryke, D.; Johns, S.J.; Kawamoto, M.; et al. Functional effects of protein sequence polymorphisms in the organic cation/ergothioneine transporter OCTN1 (SLC22A4). Pharmacogenetics Genom. 2007, 17, 773-782. [CrossRef] [PubMed]

75. Toh, D.S.; Cheung, F.S.; Murray, M.; Pern, T.K.; Lee, E.J.; Zhou, F. Functional analysis of novel variants in the organic cation/ergothioneine transporter 1 identified in Singapore populations. Mol. Pharm. 2013, 10, 2509-2516. [CrossRef] [PubMed]

76. Zhou, F.; Zhu, L.; Wang, K.; Murray, M. Recent advance in the pharmacogenomics of human solute carrier transporters (SLCS) in drug disposition. Adv. Drug Deliv. Rev. 2017, 116, 21-36. [CrossRef] [PubMed]

77. Koepsell, H. The SLC22 family with transporters of organic cations, anions and zwitterions. Mol. Aspects Med. 2013, 34, 413-435. [CrossRef] [PubMed]

78. Nigam, S.K.; Bush, K.T.; Martovetsky, G.; Ahn, S.Y.; Liu, H.C.; Richard, E.; Bhatnagar, V.; Wu, W. The organic anion transporter (OAT) family: A systems biology perspective. Physiol. Rev. 2015, 95, 83-123. [CrossRef] [PubMed]

79. Burckhardt, G.; Burckhardt, B.C. In vitro and in vivo evidence of the importance of organic anion transporters (OATS) in drug therapy. In Handbook of Experimental Pharmacology; Springer: Berlin/Heidelberg, Germany, 2011; pp. 29-104.

80. Hilgendorf, C.; Ahlin, G.; Seithel, A.; Artursson, P.; Ungell, A.L.; Karlsson, J. Expression of thirty-six drug transporter genes in human intestine, liver, kidney, and organotypic cell lines. Drug Metab. Dispos. Biol. Fate Chem. 2007, 35, 1333-1340. [CrossRef] [PubMed]

81. Wu, W.; Bush, K.T.; Liu, H.C.; Zhu, C.; Abagyan, R.; Nigam, S.K. Shared ligands between organic anion transporters (OAT1 and OAT6) and odorant receptors. Drug Metab. Dispos. Biol. Fate Chem. 2015, 43, 1855-1863. [CrossRef] [PubMed]

82. Ueo, H.; Motohashi, H.; Katsura, T.; Inui, K. Human organic anion transporter hOAT3 is a potent transporter of cephalosporin antibiotics, in comparison with hOAT1. Biochem. Pharmacol. 2005, 70, 1104-1113. [CrossRef] [PubMed]

83. Yamada, A.; Maeda, K.; Kamiyama, E.; Sugiyama, D.; Kondo, T.; Shiroyanagi, Y.; Nakazawa, H.; Okano, T.; Adachi, M.; Schuetz, J.D.; et al. Multiple human isoforms of drug transporters contribute to the hepatic and renal transport of olmesartan, a selective antagonist of the angiotensinII AT1-receptor. Drug Metab. Dispos. 2007, 35, 2166-2176. [CrossRef] [PubMed]

84. Hasannejad, H.; Takeda, M.; Taki, K.; Shin, H.J.; Babu, E.; Jutabha, P.; Khamdang, S.; Aleboyeh, M.; Onozato, M.L.; Tojo, A.; et al. Interactions of human organic anion transporters with diuretics. J. Pharmacol. Exp. Ther. 2004, 308, 1021-1029. [CrossRef] [PubMed]

85. Cihlar, T.; Lin, D.C.; Pritchard, J.B.; Fuller, M.D.; Mendel, D.B.; Sweet, D.H. The antiviral nucleotide analogs cidofovir and adefovir are novel substrates for human and rat renal organic anion transporter 1. Mol. Pharmacol. 1999, 56, 570-580. [CrossRef] [PubMed]

86. Cheng, Y.; Vapurcuyan, A.; Shahidullah, M.; Aleksunes, L.M.; Pelis, R.M. Expression of organic anion transporter 2 in the human kidney and its potential role in the tubular secretion of guanine-containing antiviral drugs. Drug Metab. Dispos. 2012, 40, 617-624. [CrossRef] [PubMed]

87. Bleasby, K.; Hall, L.A.; Perry, J.L.; Mohrenweiser, H.W.; Pritchard, J.B. Functional consequences of single nucleotide polymorphisms in the human organic anion transporter hOAT1 (SLC22A6). J. Pharmacol. Exp. Ther. 2005, 314, 923-931. [CrossRef] [PubMed]

88. Takeda, M.; Babu, E.; Narikawa, S.; Endou, H. Interaction of human organic anion transporters with various cephalosporin antibiotics. Eur. J. Pharmacol. 2002, 438, 137-142. [CrossRef]

89. Burckhardt, B.C.; Brai, S.; Wallis, S.; Krick, W.; Wolff, N.A.; Burckhardt, G. Transport of cimetidine by flounder and human renal organic anion transporter 1. Am. J. Physiol. Renal Physiol. 2003, 284, F503-F509. [CrossRef] [PubMed] 
90. Uwai, Y.; Taniguchi, R.; Motohashi, H.; Saito, H.; Okuda, M.; Inui, K. Methotrexate-loxoprofen interaction: Involvement of human organic anion transporters hOAT1 and hOAT3. Drug Metab. Pharmacokinet. 2004, 19, 369-374. [CrossRef] [PubMed]

91. Cihlar, T.; Ho, E.S. Fluorescence-based assay for the interaction of small molecules with the human renal organic anion transporter 1. Anal. Biochem. 2000, 283, 49-55. [CrossRef] [PubMed]

92. Chu, X.Y.; Bleasby, K.; Yabut, J.; Cai, X.; Chan, G.H.; Hafey, M.J.; Xu, S.; Bergman, A.J.; Braun, M.P.; Dean, D.C.; et al. Transport of the dipeptidyl peptidase-4 inhibitor sitagliptin by human organic anion transporter 3 , organic anion transporting polypeptide $4 \mathrm{C} 1$, and multidrug resistance P-glycoprotein. J. Pharmacol. Exp. Ther. 2007, 321, 673-683. [CrossRef] [PubMed]

93. Khamdang, S.; Takeda, M.; Noshiro, R.; Narikawa, S.; Enomoto, A.; Anzai, N.; Piyachaturawat, P.; Endou, H. Interactions of human organic anion transporters and human organic cation transporters with nonsteroidal anti-inflammatory drugs. J. Pharmacol. Exp. Ther. 2002, 303, 534-539. [CrossRef] [PubMed]

94. Mulato, A.S.; Ho, E.S.; Cihlar, T. Nonsteroidal anti-inflammatory drugs efficiently reduce the transport and cytotoxicity of adefovir mediated by the human renal organic anion transporter 1. J. Pharmacol. Exp. Ther. 2000, 295, 10-15. [PubMed]

95. Morrissey, K.M.; Stocker, S.L.; Wittwer, M.B.; Xu, L.; Giacomini, K.M. Renal transporters in drug development. Annu. Rev. Pharmacol. Toxicol. 2013, 53, 503-529. [CrossRef] [PubMed]

96. Li, M.; Anderson, G.D.; Wang, J. Drug-drug interactions involving membrane transporters in the human kidney. Expert Opin. Drug Metab. Toxicol. 2006, 2, 505-532. [CrossRef] [PubMed]

97. Sun, W.; Wu, R.R.; van Poelje, P.D.; Erion, M.D. Isolation of a family of organic anion transporters from human liver and kidney. Biochem. Biophys. Res. Commun. 2001, 283, 417-422. [CrossRef] [PubMed]

98. Sekine, T.; Cha, S.H.; Tsuda, M.; Apiwattanakul, N.; Nakajima, N.; Kanai, Y.; Endou, H. Identification of multispecific organic anion transporter 2 expressed predominantly in the liver. FEBS Lett. 1998, 429, 179-182. [CrossRef]

99. Marada, V.V.; Florl, S.; Kuhne, A.; Muller, J.; Burckhardt, G.; Hagos, Y. Interaction of human organic anion transporter 2 (OAT2) and sodium taurocholate cotransporting polypeptide (NTCP) with antineoplastic drugs. Pharmacol. Res. 2015, 91, 78-87. [CrossRef] [PubMed]

100. Kobayashi, Y.; Ohshiro, N.; Sakai, R.; Ohbayashi, M.; Kohyama, N.; Yamamoto, T. Transport mechanism and substrate specificity of human organic anion transporter 2 (hOAT2 [SLC22A7]). J. Pharm. Pharmacol. 2005, 57, 573-578. [CrossRef] [PubMed]

101. Tashiro, A.; Tatsumi, S.; Takeda, R.; Naka, A.; Matsuoka, H.; Hashimoto, Y.; Hatta, K.; Maeda, K.; Kamoshida, S. High expression of organic anion transporter 2 and organic cation transporter 2 is an independent predictor of good outcomes in patients with metastatic colorectal cancer treated with FOLFOX-based chemotherapy. Am. J. Cancer Res. 2014, 4, 528-536. [PubMed]

102. Tahara, H.; Kusuhara, H.; Endou, H.; Koepsell, H.; Imaoka, T.; Fuse, E.; Sugiyama, Y. A species difference in the transport activities of $\mathrm{H} 2$ receptor antagonists by rat and human renal organic anion and cation transporters. J. Pharmacol. Exp. Ther. 2005, 315, 337-345. [CrossRef] [PubMed]

103. Kobayashi, Y.; Sakai, R.; Ohshiro, N.; Ohbayashi, M.; Kohyama, N.; Yamamoto, T. Possible involvement of organic anion transporter 2 on the interaction of theophylline with erythromycin in the human liver. Drug Metab. Dispos. 2005, 33, 619-622. [CrossRef] [PubMed]

104. Babu, E.; Takeda, M.; Narikawa, S.; Kobayashi, Y.; Yamamoto, T.; Cha, S.H.; Sekine, T.; Sakthisekaran, D.; Endou, H. Human organic anion transporters mediate the transport of tetracycline. Jpn. J. Pharmacol. 2002, 88, 69-76. [CrossRef] [PubMed]

105. Burckhardt, G. Drug transport by organic anion transporters (OATs). Pharmacol. Ther. 2012, 136, $106-130$. [CrossRef] [PubMed]

106. Zhang, Y.; Han, Y.H.; Putluru, S.P.; Matta, M.K.; Kole, P.; Mandlekar, S.; Furlong, M.T.; Liu, T.; Iyer, R.A.; Marathe, P.; et al. Diclofenac and its ACYL glucuronide: Determination of in vivo exposure in human subjects and characterization as human drug transporter substrates in vitro. Drug Metab. Dispos. 2016, 44, 320-328. [CrossRef] [PubMed]

107. Nagle, M.A.; Truong, D.M.; Dnyanmote, A.V.; Ahn, S.Y.; Eraly, S.A.; Wu, W.; Nigam, S.K. Analysis of three-dimensional systems for developing and mature kidneys clarifies the role of OAT1 and OAT3 in antiviral handling. J. Biol. Chem. 2011, 286, 243-251. [CrossRef] [PubMed] 
108. VanWert, A.L.; Sweet, D.H. Impaired clearance of methotrexate in organic anion transporter 3 (SLC22A8) knockout mice: A gender specific impact of reduced folates. Pharm. Res. 2008, 25, 453-462. [CrossRef] [PubMed]

109. Vanwert, A.L.; Bailey, R.M.; Sweet, D.H. Organic anion transporter 3 (Oat3/Slc22a8) knockout mice exhibit altered clearance and distribution of penicillin G. Am. J. Physiol. Ren. Physiol. 2007, 293, F1332-F1341. [CrossRef] [PubMed]

110. Maeda, K.; Tian, Y.; Fujita, T.; Ikeda, Y.; Kumagai, Y.; Kondo, T.; Tanabe, K.; Nakayama, H.; Horita, S.; Kusuhara, H.; et al. Inhibitory effects of $p$-aminohippurate and probenecid on the renal clearance of adefovir and benzylpenicillin as probe drugs for organic anion transporter (OAT) 1 and OAT3 in humans. Eur. J. Pharm. Sci. 2014, 59, 94-103. [CrossRef] [PubMed]

111. Windass, A.S.; Lowes, S.; Wang, Y.; Brown, C.D. The contribution of organic anion transporters OAT1 and OAT3 to the renal uptake of rosuvastatin. J. Pharmacol. Exp. Ther. 2007, 322, 1221-1227. [CrossRef] [PubMed]

112. Khamdang, S.; Takeda, M.; Shimoda, M.; Noshiro, R.; Narikawa, S.; Huang, X.L.; Enomoto, A.; Piyachaturawat, P.; Endou, H. Interactions of human- and rat-organic anion transporters with pravastatin and cimetidine. J. Pharmacol. Sci. 2004, 94, 197-202. [CrossRef] [PubMed]

113. Takeda, M.; Khamdang, S.; Narikawa, S.; Kimura, H.; Hosoyamada, M.; Cha, S.H.; Sekine, T.; Endou, H. Characterization of methotrexate transport and its drug interactions with human organic anion transporters. J. Pharmacol. Exp. Ther. 2002, 302, 666-671. [CrossRef] [PubMed]

114. Iwaki, M.; Shimada, H.; Irino, Y.; Take, M.; Egashira, S. Inhibition of methotrexate uptake via organic anion transporters OAT1 and OAT3 by glucuronides of nonsteroidal anti-inflammatory drugs. Biol. Pharm. Bull. 2017, 40, 926-931. [CrossRef] [PubMed]

115. Honjo, H.; Uwai, Y.; Aoki, Y.; Iwamoto, K. Stereoselective inhibitory effect of flurbiprofen, ibuprofen and naproxen on human organic anion transporters hOAT1 and hOAT3. Biopharm. Drug Dispos. 2011, 32, 518-524. [CrossRef] [PubMed]

116. Wang, C.; Wang, C.; Liu, Q.; Meng, Q.; Cang, J.; Sun, H.; Peng, J.; Ma, X.; Huo, X.; Liu, K. Aspirin and probenecid inhibit organic anion transporter 3-mediated renal uptake of cilostazol and probenecid induces metabolism of cilostazol in the rat. Drug Metab. Dispos. 2014, 42, 996-1007. [CrossRef] [PubMed]

117. Vanwert, A.L.; Srimaroeng, C.; Sweet, D.H. Organic anion transporter 3 (Oat3/Slc22a8) interacts with carboxyfluoroquinolones, and deletion increases systemic exposure to ciprofloxacin. Mol. Pharmacol. 2008, 74, 122-131. [CrossRef] [PubMed]

118. Reese, M.J.; Bowers, G.D.; Humphreys, J.E.; Gould, E.P.; Ford, S.L.; Webster, L.O.; Polli, J.W. Drug interaction profile of the HIV integrase inhibitor cabotegravir: Assessment from in vitro studies and a clinical investigation with midazolam. Xenobiotica 2016, 46, 445-456. [CrossRef] [PubMed]

119. Wikoff, W.R.; Nagle, M.A.; Kouznetsova, V.L.; Tsigelny, I.F.; Nigam, S.K. Untargeted metabolomics identifies enterobiome metabolites and putative uremic toxins as substrates of organic anion transporter 1 (OAT1). J. Proteome Res. 2011, 10, 2842-2851. [CrossRef] [PubMed]

120. Bush, K.T.; Wu, W.; Lun, C.; Nigam, S.K. The drug transporter OAT3 (SLC22A8) and endogenous metabolite communication via the gut-liver-kidney axis. J. Biol. Chem. 2017, 292, 15789-15803. [CrossRef] [PubMed]

121. Cha, S.H.; Sekine, T.; Kusuhara, H.; Yu, E.; Kim, J.Y.; Kim, D.K.; Sugiyama, Y.; Kanai, Y.; Endou, H. Molecular cloning and characterization of multispecific organic anion transporter 4 expressed in the placenta. J. Biol. Chem. 2000, 275, 4507-4512. [CrossRef] [PubMed]

122. Hagos, Y.; Bahn, A.; Vormfelde, S.V.; Brockmoller, J.; Burckhardt, G. Torasemide transport by organic anion transporters contributes to hyperuricemia. J. Am. Soc. Nephrol. 2007, 18, 3101-3109. [CrossRef] [PubMed]

123. Anzai, N.; Jutabha, P.; Enomoto, A.; Yokoyama, H.; Nonoguchi, H.; Hirata, T.; Shiraya, K.; He, X.; Cha, S.H.; Takeda, M.; et al. Functional characterization of rat organic anion transporter 5 (SLC22A19) at the apical membrane of renal proximal tubules. J. Pharmacol. Exp. Ther. 2005, 315, 534-544. [CrossRef] [PubMed]

124. Malnic, B.; Gonzalez-Kristeller, D.C.; Gutiyama, L.M. Odorant receptors. In The Neurobiology of Olfaction; Menini, A., Ed.; CRC Press: Boca Raton, FL, USA, 2010.

125. Zimmerman, E.I.; Gibson, A.A.; Hu, S.; Vasilyeva, A.; Orwick, S.J.; Du, G.; Mascara, G.P.; Ong, S.S.; Chen, T.; Vogel, P.; et al. Multikinase inhibitors induce cutaneous toxicity through OAT6-mediated uptake and MAP3K7-driven cell death. Cancer Res. 2016, 76, 117-126. [CrossRef] [PubMed] 
126. Shin, H.J.; Anzai, N.; Enomoto, A.; He, X.; Kim, D.K.; Endou, H.; Kanai, Y. Novel liver-specific organic anion transporter OAT7 that operates the exchange of sulfate conjugates for short chain fatty acid butyrate. Hepatology 2007, 45, 1046-1055. [CrossRef] [PubMed]

127. Emami Riedmaier, A.; Burk, O.; van Eijck, B.A.; Schaeffeler, E.; Klein, K.; Fehr, S.; Biskup, S.; Muller, S.; Winter, S.; Zanger, U.M.; et al. Variability in hepatic expression of organic anion transporter 7/SLC22A9, a novel pravastatin uptake transporter: Impact of genetic and regulatory factors. Pharmacogenomics J. 2016, 16, 341-351. [CrossRef] [PubMed]

128. Bahn, A.; Hagos, Y.; Reuter, S.; Balen, D.; Brzica, H.; Krick, W.; Burckhardt, B.C.; Sabolic, I.; Burckhardt, G. Identification of a new urate and high affinity nicotinate transporter, hOAT10 (SLC22A13). J. Biol. Chem. 2008, 283, 16332-16341. [CrossRef] [PubMed]

129. Enomoto, A.; Kimura, H.; Chairoungdua, A.; Shigeta, Y.; Jutabha, P.; Cha, S.H.; Hosoyamada, M.; Takeda, M.; Sekine, T.; Igarashi, T.; et al. Molecular identification of a renal urate anion exchanger that regulates blood urate levels. Nature 2002, 417, 447-452. [CrossRef] [PubMed]

130. Shin, H.J.; Takeda, M.; Enomoto, A.; Fujimura, M.; Miyazaki, H.; Anzai, N.; Endou, H. Interactions of urate transporter URAT1 in human kidney with uricosuric drugs. Nephrology 2011, 16, 156-162. [CrossRef] [PubMed]

131. Xu, L.; Shi, Y.; Zhuang, S.; Liu, N. Recent advances on uric acid transporters. Oncotarget 2017, 8, 100852-100862. [CrossRef] [PubMed]

132. Bhatnagar, V.; Richard, E.L.; Wu, W.; Nievergelt, C.M.; Lipkowitz, M.S.; Jeff, J.; Maihofer, A.X.; Nigam, S.K. Analysis of ABCG2 and other urate transporters in uric acid homeostasis in chronic kidney disease: Potential role of remote sensing and signaling. Clin. Kidney J. 2016, 9, 444-453. [CrossRef] [PubMed]

133. Zair, Z.M.; Eloranta, J.J.; Stieger, B.; Kullak-Ublick, G.A. Pharmacogenetics of OATP (SLC21/SLCO), OAT and OCT (SLC22) and PEPT (SLC15) transporters in the intestine, liver and kidney. Pharmacogenomics 2008, 9, 597-624. [CrossRef] [PubMed]

134. Fujita, T.; Brown, C.; Carlson, E.J.; Taylor, T.; de la Cruz, M.; Johns, S.J.; Stryke, D.; Kawamoto, M.; Fujita, K.; Castro, R.; et al. Functional analysis of polymorphisms in the organic anion transporter, SLC22A6 (OAT1). Pharmacogenetics Genom. 2005, 15, 201-209. [CrossRef]

135. Shen, H.; Lai, Y.; Rodrigues, A.D. Organic anion transporter 2: An enigmatic human solute carrier. Drug Metab. Dispos. Biol. Fate Chem. 2017, 45, 228-236. [CrossRef] [PubMed]

136. Cropp, C.D.; Komori, T.; Shima, J.E.; Urban, T.J.; Yee, S.W.; More, S.S.; Giacomini, K.M. Organic anion transporter 2 (SLC22A7) is a facilitative transporter of CGMP. Mol. Pharmacol. 2008, 73, 1151-1158. [CrossRef] [PubMed]

137. Erdman, A.R.; Mangravite, L.M.; Urban, T.J.; Lagpacan, L.L.; Castro, R.A.; de la Cruz, M.; Chan, W.; Huang, C.C.; Johns, S.J.; Kawamoto, M.; et al. The human organic anion transporter 3 (OAT3; SLC22A8): Genetic variation and functional genomics. Am. J. Physiol. Ren. Physiol. 2006, 290, F905-F912. [CrossRef] [PubMed]

138. Yee, S.W.; Nguyen, A.N.; Brown, C.; Savic, R.M.; Zhang, Y.; Castro, R.A.; Cropp, C.D.; Choi, J.H.; Singh, D.; Tahara, H.; et al. Reduced renal clearance of cefotaxime in Asians with a low-frequency polymorphism of OAT3 (SLC22A8). J. Pharm. Sci. 2013, 102, 3451-3457. [CrossRef] [PubMed]

139. Ivanyuk, A.; Livio, F.; Biollaz, J.; Buclin, T. Renal drug transporters and drug interactions. Clin. Pharmacokinet. 2017, 56, 825-892. [CrossRef] [PubMed]

140. Zhou, F.; Zhu, L.; Cui, P.H.; Church, W.B.; Murray, M. Functional characterization of nonsynonymous single nucleotide polymorphisms in the human organic anion transporter 4 (hOAT4). Br. J. Pharmacol. 2010, 159, 419-427. [CrossRef] [PubMed]

141. Vormfelde, S.V.; Schirmer, M.; Hagos, Y.; Toliat, M.R.; Engelhardt, S.; Meineke, I.; Burckhardt, G.; Nurnberg, P.; Brockmoller, J. Torsemide renal clearance and genetic variation in luminal and basolateral organic anion transporters. Br. J. Clin. Pharmacol. 2006, 62, 323-335. [CrossRef] [PubMed]

142. Ichida, K.; Hosoyamada, M.; Hisatome, I.; Enomoto, A.; Hikita, M.; Endou, H.; Hosoya, T. Clinical and molecular analysis of patients with renal hypouricemia in Japan-influence of URAT1 gene on urinary urate excretion. J. Am. Soc. Nephrol. JASN 2004, 15, 164-173. [CrossRef] [PubMed]

143. Ogasawara, K.; Terada, T.; Motohashi, H.; Asaka, J.; Aoki, M.; Katsura, T.; Kamba, T.; Ogawa, O.; Inui, K. Analysis of regulatory polymorphisms in organic ion transporter genes (SLC22A) in the kidney. J. Hum. Genet. 2008, 53, 607-614. [CrossRef] [PubMed] 
144. Shin, H.J.; Lee, C.H.; Lee, S.S.; Song, I.S.; Shin, J.G. Identification of genetic polymorphisms of human oat1 and OAT2 genes and their relationship to hOAT2 expression in human liver. Clin. Chim. Acta Int. J. Clin. Chem. 2010, 411, 99-105. [CrossRef] [PubMed]

145. Visscher, H.; Rassekh, S.R.; Sandor, G.S.; Caron, H.N.; van Dalen, E.C.; Kremer, L.C.; van der Pal, H.J.; Rogers, P.C.; Rieder, M.J.; Carleton, B.C.; et al. Genetic variants in SLC22A17 and SLC22A7 are associated with anthracycline-induced cardiotoxicity in children. Pharmacogenomics 2015, 16, 1065-1076. [CrossRef] [PubMed]

146. Pellicer, M.; Garcia-Gonzalez, X.; Garcia, M.I.; Robles, L.; Gravalos, C.; Garcia-Alfonso, P.; Pachon, V.; Longo, F.; Martinez, V.; Blanco, C.; et al. Identification of new SNPs associated with severe toxicity to capecitabine. Pharmacol. Res. 2017, 120, 133-137. [CrossRef] [PubMed]

147. Li, Q.; Shu, Y. Role of solute carriers in response to anticancer drugs. Mol. Cell. Ther. 2014, 2, 15. [CrossRef] [PubMed]

148. El-Gebali, S.; Bentz, S.; Hediger, M.A.; Anderle, P. Solute carriers (SLCs) in cancer. Mol. Aspects Med. 2013, 34, 719-734. [CrossRef] [PubMed]

149. Angelini, S.; Pantaleo, M.A.; Ravegnini, G.; Zenesini, C.; Cavrini, G.; Nannini, M.; Fumagalli, E.; Palassini, E.; Saponara, M.; Di Battista, M.; et al. Polymorphisms in OCTN1 and OCTN2 transporters genes are associated with prolonged time to progression in unresectable gastrointestinal stromal tumours treated with imatinib therapy. Pharmacol. Res. 2013, 68, 1-6. [CrossRef] [PubMed]

150. Kerb, R.; Brinkmann, U.; Chatskaia, N.; Gorbunov, D.; Gorboulev, V.; Mornhinweg, E.; Keil, A.; Eichelbaum, M.; Koepsell, H. Identification of genetic variations of the human organic cation transporter hOCT1 and their functional consequences. Pharmacogenetics 2002, 12, 591-595. [CrossRef] [PubMed]

151. Herraez, E.; Lozano, E.; Macias, R.I.; Vaquero, J.; Bujanda, L.; Banales, J.M.; Marin, J.J.; Briz, O. Expression of SLC22A1 variants may affect the response of hepatocellular carcinoma and cholangiocarcinoma to sorafenib. Hepatology 2013, 58, 1065-1073. [CrossRef] [PubMed]

152. Shu, Y.; Leabman, M.K.; Feng, B.; Mangravite, L.M.; Huang, C.C.; Stryke, D.; Kawamoto, M.; Johns, S.J.; DeYoung, J.; Carlson, E.; et al. Evolutionary conservation predicts function of variants of the human organic cation transporter, OCT1. Proc. Natl. Acad. Sci. USA 2003, 100, 5902-5907. [CrossRef] [PubMed]

153. Lozano, E.; Herraez, E.; Briz, O.; Robledo, V.S.; Hernandez-Iglesias, J.; Gonzalez-Hernandez, A.; Marin, J.J. Role of the plasma membrane transporter of organic cations OCT1 and its genetic variants in modern liver pharmacology. Biomed. Res. Int. 2013, 2013, 692071. [CrossRef] [PubMed]

154. Di Paolo, A.; Polillo, M.; Capecchi, M.; Cervetti, G.; Barate, C.; Angelini, S.; Guerrini, F.; Fontanelli, G.; Arici, R.; Ciabatti, E.; et al. The c.480C >G polymorphism of hOCT1 influences imatinib clearance in patients affected by chronic myeloid leukemia. Pharmacogenomics J. 2014, 14, 328-335. [CrossRef] [PubMed]

155. Galimberti, S.; Bucelli, C.; Arrigoni, E.; Barate, C.; Grassi, S.; Ricci, F.; Guerrini, F.; Ciabatti, E.; Fava, C.; D'Avolio, A.; et al. The hOCT1 and ABCB1 polymorphisms do not influence the pharmacodynamics of nilotinib in chronic myeloid leukemia. Oncotarget 2017, 8, 88021-88033. [CrossRef] [PubMed]

156. Arimany-Nardi, C.; Montraveta, A.; Lee-Verges, E.; Puente, X.S.; Koepsell, H.; Campo, E.; Colomer, D.; Pastor-Anglada, M. Human organic cation transporter 1 (hOCT1) as a mediator of bendamustine uptake and cytotoxicity in chronic lymphocytic leukemia (CLL) cells. Pharmacogenomics J. 2015, 15, 363-371. [CrossRef] [PubMed]

157. Zheng, X.; Liu, Y.; Yu, Q.; Wang, H.; Tan, F.; Zhu, Q.; Yuan, L.; Jiang, H.; Zeng, S.; Yu, L. Response to comment on "epigenetic activation of the drug transporter OCT2 sensitizes renal cell carcinoma to oxaliplatin". Sci. Transl. Med. 2017, 9. [CrossRef] [PubMed]

158. Suenaga, M.; Schirripa, M.; Cao, S.; Zhang, W.; Yang, D.; Dadduzio, V.; Salvatore, L.; Borelli, B.; Pietrantonio, F.; Ning, Y.; et al. Potential role of polymorphisms in the transporter genes ent1 and MATE1/OCT2 in predicting TAS-102 efficacy and toxicity in patients with refractory metastatic colorectal cancer. Eur. J. Cancer 2017, 86, 197-206. [CrossRef] [PubMed]

159. Chen, L.; Hong, C.; Chen, E.C.; Yee, S.W.; Xu, L.; Almof, E.U.; Wen, C.; Fujii, K.; Johns, S.J.; Stryke, D.; et al. Genetic and epigenetic regulation of the organic cation transporter 3, SLC22A3. Pharmacogenomics J. 2013, 13, 110-120. [CrossRef] [PubMed]

160. Cui, R.; Okada, Y.; Jang, S.G.; Ku, J.L.; Park, J.G.; Kamatani, Y.; Hosono, N.; Tsunoda, T.; Kumar, V.; Tanikawa, C.; et al. Common variant in 6q26-q27 is associated with distal colon cancer in an Asian population. Gut 2011, 60, 799-805. [CrossRef] [PubMed] 
161. Grisanzio, C.; Werner, L.; Takeda, D.; Awoyemi, B.C.; Pomerantz, M.M.; Yamada, H.; Sooriakumaran, P.; Robinson, B.D.; Leung, R.; Schinzel, A.C.; et al. Genetic and functional analyses implicate the NUDT11, HNF1B, and SLC22A3 genes in prostate cancer pathogenesis. Proc. Natl. Acad. Sci. USA 2012, 109, 11252-11257. [CrossRef] [PubMed]

162. Angelini, S.; Soverini, S.; Ravegnini, G.; Barnett, M.; Turrini, E.; Thornquist, M.; Pane, F.; Hughes, T.P.; White, D.L.; Radich, J.; et al. Association between imatinib transporters and metabolizing enzymes genotype and response in newly diagnosed chronic myeloid leukemia patients receiving imatinib therapy. Haematologica 2013, 98, 193-200. [CrossRef] [PubMed]

163. VanWert, A.L.; Gionfriddo, M.R.; Sweet, D.H. Organic anion transporters: Discovery, pharmacology, regulation and roles in pathophysiology. Biopharm. Drug Dispos. 2010, 31, 1-71. [CrossRef] [PubMed]

164. Srimaroeng, C.; Perry, J.L.; Pritchard, J.B. Physiology, structure, and regulation of the cloned organic anion transporters. Xenobiotica 2008, 38, 889-935. [CrossRef] [PubMed]

165. Pelis, R.M.; Wright, S.H. SLC22, SLC44, and SLC47 transporters-Organic anion and cation transporters: Molecular and cellular properties. Curr. Top. Membr. 2014, 73, 233-261. [PubMed]

166. Schaeffeler, E.; Hellerbrand, C.; Nies, A.T.; Winter, S.; Kruck, S.; Hofmann, U.; van der Kuip, H.; Zanger, U.M.; Koepsell, H.; Schwab, M. DNA methylation is associated with downregulation of the organic cation transporter OCT1 (SLC22A1) in human hepatocellular carcinoma. Genome Med. 2011, 3, 82. [CrossRef] [PubMed]

(C) 2018 by the authors. Licensee MDPI, Basel, Switzerland. This article is an open access article distributed under the terms and conditions of the Creative Commons Attribution (CC BY) license (http:/ / creativecommons.org/licenses/by/4.0/). 